Surveys

\title{
Other-regarding preferences and pro-environmental behaviour: An interdisciplinary review of experimental studies
}

\author{
Nicolai Heinz ${ }^{\text {a, b, * }}$, Ann-Kathrin Koessler ${ }^{\text {a,c }}$ \\ ${ }^{a}$ Institute of Environmental Systems Research (IUSF), Osnabrück University, Osnabrück, Germany \\ ${ }^{\mathrm{b}}$ Environmental Politics, Helmholtz Centre for Environmental Research (UFZ), Leipzig, Germany \\ ${ }^{\mathrm{c}}$ Department of Geography and Environment, London School of Economics, London, United Kingdom
}

\section{A R T I C L E I N F O}

\section{JEL codes:}

D90

Q56

Y80

Keywords:

Pro-environmental behaviour

Other-regarding preferences

Preference activation

Empathic concern

Experiments

Review

\begin{abstract}
A B S T R A C T
Pro-environmental behaviour (PEB) is often promoted by reinforcing or highlighting own benefits. However, considering that actors also care about the outcomes for others (i.e. they hold other-regarding preferences), PEB may also be encouraged by addressing these other-regarding preferences. In this paper, we review the results from social science experiments where interventions addressing other-regarding preferences were used to promote PEB. Based on our synthesis, we conclude that addressing other-regarding preferences can be effective in promoting (various types of) PEB in some, but not in all instances. Whether an intervention was effective depended inter alia on the pre-established preferences, cost structures and the perceived cooperation of others. Effective interventions included the provision of information on behavioural consequences, perspective-taking, direct appeals, framing and re-categorization. The interventions worked by activating other-regarding preferences, raising awareness about adverse consequences, evoking empathic concern and expanding the moral circle. We propose to take these findings as an impulse to examine policy instruments and institutions in terms of whether they activate and strengthen other-regarding preferences, thereby enabling collective engagement in PEB.
\end{abstract}

\section{Introduction}

In order to promote a collective change of individual behaviour which is compatible with the planetary boundaries, environmental policy often addresses actors' self-regarding preferences, e.g. via economic incentives. Yet, numerous studies have shown that doing so could potentially crowd-out the intrinsic motivation to act (Rode et al., 2015). An alternative approach can be to address actors' other-regarding preferences to promote pro-environmental behaviour (PEB). Otherregarding preferences are preferences that attach value to the wellbeing of others as ends in themselves (other humans, species or nature as a whole). Since most PEB can be understood as other-regarding behaviour since it involves giving up own resources to the benefit of others, such preferences seem to be in line with PEB. Thus, unsurprisingly, it is a well-established empirical finding that other-regarding preferences (or values) are positively associated with proenvironmental behaviour (for overviews see Schultz and Zelezny, 1998; Schultz and Zelezny, 1999; Dietz et al., 2005). The experimental literature goes a step further by testing interventions addressing other- regarding preferences (we will call them other-regarding interventions) aimed at promoting $\mathrm{PEB}$, sometimes in comparison to interventions addressing self-regarding preferences. Thus, it provides us with insights on if and how other-regarding interventions work to promote PEB. This paper reviews the experimental results.

More specially, we focus the review on the following questions:

- Is addressing other-regarding preferences an effective way to increase PEB?

- If so, which interventions are effective, through which channels do they work and for which types of PEB do they have an effect?

- Which factors explain when and for whom these interventions were effective in promoting PEB?

- How do interventions addressing other-regarding preferences compare to interventions addressing self-regarding preferences?

To answer these questions, we review experimental findings from the different behavioural sciences. Synthesizing insights across disciplinary boundaries can be very fruitful, as for example, the advancements in

\footnotetext{
* Corresponding author at: Helmholtz Centre for Environmental Research (UFZ), Permoserstr. 15, 04318 Leipzig, Germany.

E-mail addresses: nicolai.heinz@ufz.de (N. Heinz), akoessler@uos.de (A.-K. Koessler).
} 
behavioural economics have shown. In this review, we selected keywords from the various social sciences in order to build a broad interdisciplinary base for our review.

The remainder of this paper is structured as follows: The next section provides a more detailed theoretical and empirical base regarding the link between other-regarding preferences and PEB. The third section explains the review method and gives an overview of the identified literature strands. The fourth section presents the findings of the reviewed experiments to answer the questions laid out above. The fifth section concludes and discusses the results in terms of their implications for research and policy.

\section{Other-regarding preferences and pro-environmental behaviour}

Pro-environmental behaviour (PEB) involves private and public behaviours that have a positive impact on the environment, including environmentally friendly consumption behaviour or acceptance of proenvironmental policies (Stern, 2000). In the absence of policy intervention, the behaviours typically involve forgoing personal advantages or accepting personal disadvantages (in terms of time, comfort or money) for the benefit of other people's well-being or nature as a whole. They can thus be regarded as other-regarding behaviours (Nolan and Schultz, 2015). PEB can also be understood as a contribution to a public good: While the positive outcome of environmental protection can be enjoyed by many, access to its benefits cannot (easily) be restricted. Under such circumstances standard economic models predict that actors will try to freeride on the efforts of others and thus environmental protection is underprovided (Olson, 1965). This is because it is assumed that self-regarding preferences determine the decision, that is (all) actors aim to maximize their self-interest with their decision-making. Following this logic, self-regarding actors are also expected to overuse natural resources and eventually degrade them (Hardin, 1968).

Considering that actors have other-regarding preferences, ${ }^{1}$ i.e. they care for the well-being of others, which consequently affects their decision-making, challenges previously derived predictions based on self-regarding preferences as sole behavioural motives. People may exhibit other-regarding preferences in the form of altruism, inequality/ inequity aversion or reciprocity (Schmidt and Fehr, 2001; Fehr and Schmidt, 2006; Cooper and Kagel, 2016). Experimental studies show in multiple ways the existence of other-regarding preferences. For instance, people share resources also when the interaction partner has no influence on the outcomes of the decision (Kahneman et al., 1986; Camerer and Thaler, 1995) and punish at own cost when they perceive others' behaviour as unfair (so called altruistic punishment - Fehr and Gächter, 2002). Other-regarding behaviour is robust even at high stakes (Cameron, 1999; Fehr et al., 2014) and takes place globally and across societies (Henrich et al., 2001). Reviewing studies from different disciplines, we needed to unify the terms of overlapping concepts that carry different names across the disciplines: we use the term preferences as an umbrella term to express actors' deep-seated and action-driving inner forces. In psychology, values are the main concept referred to in this regard, with prosocial or altruistic/biospheric value orientations

\footnotetext{
${ }^{1}$ Regard for others may by understood in two ways: First, individuals may be other-regarding in the sense that they intrinsically value others and express this valuation in their actions, e.g. they act to decrease suffering of others or to increase their well-being. Second, individuals may be other-regarding in the sense that they care how others see them and evaluate their actions. While some behaviour may appear to be other-regarding in the first sense, it may actually be performed only due to the latter, i.e., to avoid social sanctions or to gain social approval, as discussed in the literature on social norms - and thus be actually motivated by self-regard. In this review, we focus on otherregardingness in the first sense. For an insightful literature review on social norms and how they can motivate PEB, please see Farrow et al. (2017).
}

(Bogaert et al., 2008) or self-transcending values (Schwartz, 1996) most closely corresponding to other-regarding preferences. In the environmental context, "others" can also encompass future generations, nonhuman species or nature as a whole (cf. Schultz, 2001).

Other-regarding preferences give reason to expect decision-making that is more pro-environmental, or in other words more otherregarding than assumed by standard economic theory. If actors care for the well-being of others, they do not want them to suffer from adverse environmental effects of their self-regarding decisions. If actors care about nature itself, they do not want it to become destroyed. However, even if all actors had strong other-regarding preferences, uncertainty about others' behaviour feeds strategic considerations to avoid being exploited by them. Overcoming this uncertainty requires a coordination of individual decisions by appropriate institutions (Ostrom, 1990). But also with regard to approving these institutions, other-regarding preferences may play a crucial role. Actors who are other-regarding may approve institutional arrangements that improve the conditions for other humans or nature itself even when they come at a cost for themselves, which is the case for many pro-environmental policies (Drews and van den Bergh, 2016).

Empirical studies from experimental economics as well as environmental and social psychology provide ample evidence for the positive link between other-regarding preferences and PEB (for overviews see Schultz and Zelezny, 1998; Schultz and Zelezny, 1999; Dietz et al., 2005). People with stronger other-regarding preferences show higher levels of pro-environmental intentions (Cheung et al., 2014); are more likely to engage in real environmental conservation activities (Karapetyan and d'Adda, 2014); are more willing to give up scarce resources for environmental protection (money - Dietz et al., 2018; time Cameron et al., 1998) and animal welfare (Frey and Pirscher, 2018); perceive personal costs of pro-environmental programs as lower (Cameron et al., 1998); and show stronger support for proenvironmental policies (Drews and van den Bergh, 2016; Bechtel et al., 2017). These findings mostly come from correlational studies and thus do not provide evidence on the causal pathways or mechanisms of how other-regarding preferences enhance PEB.

The empirical findings also suggest that neither other-regarding preferences nor their impact on decision-making are stable or uniform across individuals/groups, time or situations. Facing the same payoff structure, people take heterogeneous decisions suggesting a varying degree of other-regarding preferences (Fehr and Schmidt, 2006). Different types of actors exist (e.g., proselfs and prosocials - Bogaert et al., 2008) and the existence of other-regarding preferences systematically varies across social groups (Awad et al., 2018). Thus, otherregarding preferences seem not to be fixed, but constituted within actors' social and institutional environments (cf. Hodgson, 2000; Dequech, 2002). Furthermore, research suggests that other-regarding preferences can change over the long-run: Experiments have shown that practicing other-regarding thought exercises do not only increase pro-social behaviour but can even alter brain structures (Klimecki et al., 2013; Singer et al., 2016). Moreover, situational differences, e.g. how situations are framed, seem to influence the role other-regarding preference take in the decision-making (e.g. Liberman et al., 2004). In summary, other-regarding preferences and their impact on decisions are not predetermined and can thus be cultivated or explicitly addressed by external interventions.

In the following sections, we aim to contribute to the understanding of this potential by reviewing experiments in which other-regarding interventions - these are interventions which increase the weight of other-regarding preferences in the decision-making process - were used to enhance PEB. Other-regarding interventions (ORI) encompass various techniques that aim at raising the willingness to contribute to the wellbeing of others as an end in itself. 


\section{Review method and strands of literature}

\subsection{Review method}

We conducted our literature review covering different disciplines and using Web of Science as a search engine. Studies had to meet the following three selection criteria to qualify for the review: They had to be (i) experimental studies that (ii) addressed other-regarding preferences and (iii) looked at the effect on pro-environmental behaviour.

Taking into account the particularities of the different behavioural science disciplines, the search string to identify studies to meet the three criteria contained terminological and conceptual variations of the three elements we were searching for. A first literature screening of various disciplinary literature strands informed the choice of terms. The following search string was used:

("pro-social preferences" OR "social preferences" OR "other-regarding preferences" $O R$ "social value orientation" $O R$ "altruistic value" $O R$ "biospheric value" $O R$ "self-transcending values" OR compassion $O R$ empathy $O R$ "empathic concern" $O R$ care $O R$ solidarity $O R$ altruis" $O R$ fairness OR justice OR "environmental preferences") AND (experiment OR "experimental study" OR "lab study" OR "field study" OR "lab experiment" $O R$ "field experiment") AND ("pro-environmental behavio"” $O R$ "environmentally significant behavio"” $O R$ "pro-environmental decision" OR PEB $O R$ "pro-environmental action" $O R$ "environmentally relevant behavio"” $O R$ "environmental practice" OR "sustainable land use" OR "sustainable behavio"” OR "conservation behavio"” OR "environmentally compatible behavio" "OR "environment-friendly behavio"” OR "green citizenship behavio"” OR "policy acceptability" OR "policy acceptance" OR "acceptance of policies" OR environment* OR sustainability)

To reduce the number of entries, papers only from disciplines with an explicit social-behavioural link were considered: behavioural sciences, economics, multidisciplinary sciences, interdisciplinary social sciences, neurosciences, political sciences, sociology and psychology, with the subdisciplines: applied psychology, developmental psychology, experimental psychology, multidisciplinary psychology, social psychology (as classified by the Web of Science). Behavioural sciences and neurosciences were dropped as they did not show any articles related to the research topic. No specification for the publication date was set, yet most studies were published from 2000 onwards. A total of 563 studies resulted from this search (as of November 2019).

All 563 abstracts were checked for our three selection criteria, which reduced the number of applicable studies substantially. We further used cited references to find additional studies to meet our selection criteria. At the end, our review is based on 26 papers covering 33 single studies. ${ }^{2}$

\subsection{Strands of literature and (inter)disciplinary classification}

In our review of the papers we could identify five strands of literature, which cite papers from the same strand but make little or no reference to papers cited in the other strands. ${ }^{3}$ Table 1 gives an overview of the identified literature strands including the methods and frequently used interventions and types of PEB.

Partly, the various strands of literature reflect the different

\footnotetext{
${ }^{2}$ Ferraro and Price (2013) and Ferraro et al. (2011) is based on the same study.

3 Three articles were not part of the identified literature strands and were added to the strand most fitting: Verplanken and Holland (2002) and Loureiro and Lima (2019) were added to the first strand due to the shared theoretical background (e.g. Schwartz's value framework); Gosnell (2018) was added to the third strand due to shared characteristic of being a large-scale field experiment.
}

disciplinary research traditions with respect to terminology and methodological approaches, especially between economics and psychology (see Table 1, column 2 and 3). ${ }^{4}$ The economics-based literature, for example, usually examines observed behaviour (such as consumption or allocation decisions in lab or field settings) whereas psychological experiments often use stated behaviours or intentions as dependent variables, which may not become actual behaviour.

\section{Review results}

In this section, we summarize the study results with respect to the questions whether and how addressing other-regarding preferences is effective in promoting PEB. Table 2 lists the main results.

While all studies addressed other-regarding preferences in the context of pro-environmental behaviour, theinterventions and operationalizations of PEB differed across studies, as did the settings in which the studies were conducted. For example, samples ranged from 40 students in a laboratory experiment (Verplanken and Holland, 2002) to more than 100,000 individuals in a field experiment by Ferraro and Price (2013). Further, the studies were conducted in different countries. ${ }^{5}$ In 4.2 and 4.3, we identify the different types of interventions and forms of PEB operationalization and discuss, building on these distinctions, the synthesized behavioural effects. Table A1 in appendix details for each study the type and size of the sample, the country in which the study was conducted and describes the particular intervention as well as PEB operationalization.

The studies we reviewed employed different control conditions: Some studies used a neutral control condition (e.g. with neutral framings or no intervention at all) while others only compared between self- and other-regarding interventions without a neutral control. Various studies employed both conditions. In total, out of our sample of 33 studies, 26 compared to a neutral control (Table 2, column 6) and 20 compared to a self-regarding intervention (column 7).

We proceed as follows: First, we look at all studies using a neutral control to investigate if other-regarding interventions increase PEB (section 4.1). Then, based on those studies that were effective in this regard (i.e. that state "yes" or "mixed" in Table 2, column 6), we review the interventions that worked to enhance PEB (section 4.2), report the types of PEB for which the behavioural change was detected (section 4.3) and summarize the channels through which the interventions presumably worked (section 4.4). We then inquire about the moderating factors that help to explain why some studies did and others did not find a positive effect on PEB (section 4.5). Lastly, we examine the general effectiveness and possible side effects of other-regarding interventions by comparing them to self-regarding interventions (section 4.6).

\subsection{Does addressing other-regarding preferences increase PEB?}

The majority of studies show a positive effect of the other-regarding interventions on PEB (see Table 2, column 6): Out of 26 experimental studies using a neutral control condition, 18 studies found that the interventions aimed at other-regarding preferences were effective in promoting PEB (for at least one of the dependent variables). Four studies

\footnotetext{
${ }^{4}$ We examined literature from sociology and political sciences, yet as these disciplines only rarely apply experimental methodology, which was one of our selection criteria, those two disciplines do not appear in our listing.

5 All studies in this review were carried out in countries of Western Europe and the U.S., meaning that the observations are based on the behaviour of WEIRD samples - subjects from white, educated, industrialized, rich and democratic societies. According to Henrich et al. (2010), these observations are not necessarily representative on a global scale.
} 
Table 1

Overview of the identified literature strands.

\begin{tabular}{|c|c|c|c|c|c|c|}
\hline Strand topic & Disciplines & Methods & Most used & Most used PEB types & \multicolumn{2}{|c|}{ Studies } \\
\hline $\begin{array}{l}\text { Other- vs. self-regarding } \\
\text { motives (incl. } \\
\text { moderation and } \\
\text { mediation analysis) }\end{array}$ & $\begin{array}{l}\text { Environmental and } \\
\text { social psychology }\end{array}$ & $\begin{array}{l}\text { Lab or online } \\
\text { studies }\end{array}$ & $\begin{array}{l}\text { Appeals, } \\
\text { information/ } \\
\text { feedback, framing }\end{array}$ & Consumption behaviour & 9 & $\begin{array}{l}\text { Bolderdijk et al., 2013a; Bolderdijk et al., } \\
\text { 2013b; Dogan et al., 2014; de Dominicis } \\
\text { et al., 2017; Evans et al., 2013; Hafner } \\
\text { et al., 2019; Hafner et al., 2017; Loureiro } \\
\text { and Lima, 2019; Verplanken and Holland, } \\
2002\end{array}$ \\
\hline $\begin{array}{l}\text { Perspective-taking, } \\
\text { compassion and } \\
\text { empathy }\end{array}$ & $\begin{array}{l}\text { Environmental and } \\
\text { social psychology, } \\
\text { experimental } \\
\text { economics }\end{array}$ & $\begin{array}{l}\text { (Framed) lab } \\
\text { experiments }\end{array}$ & $\begin{array}{l}\text { Induced } \\
\text { perspective-taking }\end{array}$ & $\begin{array}{l}\text { Consumption behaviour, non- } \\
\text { activist public sphere } \\
\text { behaviour, organizational } \\
\text { behaviour (in framed lab } \\
\text { experiments) }\end{array}$ & 7 & $\begin{array}{l}\text { Berenguer, 2007; Czap et al., 2012; Czap } \\
\text { et al., 2015; Ovchinnikova et al., 2009; } \\
\text { Pahl and Bauer, 2013; Pfattheicher et al., } \\
\text { 2016; Shelton and Rogers, } 1981\end{array}$ \\
\hline $\begin{array}{l}\text { Other- vs. self-regarding } \\
\text { motives in an applied } \\
\text { context }\end{array}$ & $\begin{array}{l}\text { Experimental } \\
\text { economics }\end{array}$ & $\begin{array}{l}\text { Large-scale } \\
\text { field } \\
\text { experiments }\end{array}$ & $\begin{array}{l}\text { Appeals, feedback, } \\
\text { framing }\end{array}$ & Consumption behaviour & 4 & $\begin{array}{l}\text { Asensio and Delmas, 2015; Ferraro and } \\
\text { Price, 2011; Ferraro and Price, 2013; } \\
\text { Gosnell, } 2018\end{array}$ \\
\hline $\begin{array}{l}\text { Framing and the } \\
\text { acceptance of policies }\end{array}$ & $\begin{array}{l}\text { Political and social } \\
\text { sciences, psychology }\end{array}$ & $\begin{array}{l}\text { Online } \\
\text { experiments }\end{array}$ & Framing & $\begin{array}{l}\text { Non-activist public sphere } \\
\text { behaviour }\end{array}$ & 4 & $\begin{array}{l}\text { Bain et al., 2012; Bernauer and McGrath, } \\
\text { 2016; Severson and Coleman, 2015; } \\
\text { Singh and Swanson, } 2017\end{array}$ \\
\hline $\begin{array}{l}\text { Morally relevant re- } \\
\text { categorization and } \\
\text { moral expansion }\end{array}$ & $\begin{array}{l}\text { Environmental and } \\
\text { social psychology }\end{array}$ & $\begin{array}{l}\text { Lab } \\
\text { experiments }\end{array}$ & $\begin{array}{l}\text { Information, re- } \\
\text { categorization }\end{array}$ & $\begin{array}{l}\text { Consumption behaviour, non- } \\
\text { activist public sphere behaviour }\end{array}$ & 2 & Bastian et al., 2019; Bratanova et al., 2012 \\
\hline
\end{tabular}

found mixed results depending on the subsample and another four studies reported null results on PEB. ${ }^{6}$

The potential of other-regarding interventions to promote PEB is backed by studies using different interventions, looking at different types of PEB and employing different experimental methodologies, indicating a reliable result. The experimental findings confirm the link between other-regarding preferences and PEB that is postulated by many of the existing correlational studies and show that this link is indeed causal. Moreover, they show that other-regarding preferences are not only stable predictors of PEB but could also be harnessed through (political) interventions and institutional frameworks. The lack of or mixed results reported by some studies already give hints that effectiveness depends on further factors (see 4.5).

\subsection{Which interventions were effective in promoting PEB?}

The experiments also provide insights into the effectiveness of specific other-regarding interventions. The interventions successfully used to promote PEB (stating "yes" and "mixed" in Table 2, column 6) consisted of the following elements or combinations thereof: (i) information or feedback on behavioural consequences, (ii) issue framing, (iii) appeals to other-regarding preferences, (iv) induced perspective-taking, and (v) morally relevant re-categorization.

Information or feedback on behavioural consequences. Several studies found that providing information about harmful impacts on others or the environment, sometimes presented also as feedback about own (altered) behaviour, increases PEB. ${ }^{7}$ Dogan et al. (2014) found a positive effect of presenting participants with environmental benefits of ecodriving on the intentions to adopt such driving behaviours and on the rated worthiness of eco-driving, compared to a control condition

\footnotetext{
${ }^{6}$ Considering the difficulty to publish studies that do not find effects, unsuccessful other-regarding interventions can be assumed to be underreported (Franco et al., 2014).

7 The studies themselves do not provide empirical answers about the underlying motivations, thus we cannot say with certainty that the behavioural change was due to other-regarding preferences. However, we think that there are good reasons to believe that behavioural responses cannot be solely explained by self-regarding preferences: For instance, a positive impact of $\mathrm{CO}_{2}$ reductions on one's own well-being cannot be felt by the individual. Thus, responding to information on behavioural consequences of reduced $\mathrm{CO}_{2}$ emissions can likely be attributed to the desire to contribute to the well-being of other people or the environment as such.
}

without any feedback. In the study by Hafner et al. (2019), feedback on reduced $\mathrm{CO}_{2}$ emissions of choosing an initially costlier heat pump raised PEB in combination with another treatment about social norms. The study by Bolderdijk et al. (2013a) gave information about the negative environmental environmental impact of bottled water and found a positive effect on PEB for subgroups of participants (see section 4.5 for a more detailed discussion on subgroup effects). Bastian et al. (2019) found that when players in a resource game were told that resource depletion leads to the death of crickets, they extracted less from the resource. The results suggest that providing information about behavioural consequences has a positive effect on PEB. As we will later discuss, this is mainly the case because certain types of actors react to the information differently.

Issue framing/priming. Framing an environmental issue in different ways, thereby emphasizing other-regarding aspects of the topic, has in some studies increased PEB. Looking at the policy dimension of PEB, Severson and Coleman (2015) found that two other-regarding frames of climate change (framing it in terms of economic equity and secular morality) increased policy support for regulatory climate change mitigation policies when compared to the control condition without any treatment. Another study by Evans et al. (2013) showed that reading other-regarding statements for car-sharing increased PEB in another behavioural domain (here recycling behaviour). Also priming otherregarding preferences, i.e. giving people unconscious cues to make the well-being of others salient (e.g. by presenting words associated with others' well-being in a seemingly unrelated task), has shown to be effective in increasing PEB (Verplanken and Holland, 2002; Ovchinnikova et al., 2009, study 1; for a subgroup also Loureiro and Lima, 2019).

Appeals to other-regarding preferences. In other studies, active appeals to other-regarding preferences were able to raise PEB. In the study by Gosnell (2018), letters were sent out to over 30,000 customers of a renewable energy supplier containing information about environmental consequences of paper vs. online billing and in one treatment additionally appealing to the customer's identity as environmental steward. Whilst there was no significant effect of the environmental information alone, a slight increase of the decisions to switch to paperless billing occurred when the identity-based appeal was added (only for those not holding a doctorate degree). In the field experiment by Ferraro and Price (2013), letters with an other-regarding appeal (to save water "for preserving our environment and our economy for future generations"), sent to more than 100,000 water users, were effective in reducing water consumption the same year, compared to a control condition in which the letters only provided technical advice. 
Table 2

Overview of study results, interventions and PEB types.

\begin{tabular}{|c|c|c|c|c|}
\hline \multirow[t]{2}{*}{ Study } & \multicolumn{2}{|l|}{ PEB } & \multicolumn{2}{|l|}{ Results } \\
\hline & Type of PEB & $\begin{array}{l}\text { Behavioural } \\
\text { measure }\end{array}$ & $\begin{array}{l}\text { Significant } \\
\text { positive } \\
\text { effect of } \\
\text { other- } \\
\text { regarding } \\
\text { intervention } \\
\text { (ORI) }\end{array}$ & $\begin{array}{l}\text { Greater } \\
\text { behavioural } \\
\text { effect: ORI } \\
\text { vs. self- } \\
\text { regarding } \\
\text { intervention } \\
\text { (SRI) }\end{array}$ \\
\hline \multicolumn{5}{|c|}{$\begin{array}{l}\text { Raising awareness about adverse consequences on others (e.g. through providing } \\
\text { feedback) }\end{array}$} \\
\hline $\begin{array}{l}\text { Asensio and } \\
\text { Delmas, } \\
2015\end{array}$ & Consumption & Obs. & n.a. & ORI \\
\hline $\begin{array}{l}\text { Bastian et al., } \\
\text { 2019, study } \\
1\end{array}$ & Consumption & Obs. & Yes & n.a. \\
\hline $\begin{array}{l}\text { Bastian et al., } \\
2019 \text {, study } \\
2\end{array}$ & Consumption & Obs. & Yes & n.a. \\
\hline $\begin{array}{l}\text { Bolderdijk } \\
\text { et al., } \\
\text { 2013a, } \\
\text { study } 3\end{array}$ & Consumption & Obs. & No & ORI \\
\hline $\begin{array}{l}\text { Bolderdijk } \\
\text { et al., 2013b }\end{array}$ & $\begin{array}{l}\text { Consumption } \\
+ \text { Public }\end{array}$ & Stated & Mixed & n.a. \\
\hline $\begin{array}{l}\text { Dogan et al., } \\
2014\end{array}$ & Consumption & Stated & Yes & Same \\
\hline $\begin{array}{l}\text { Hafner et al., } \\
2017\end{array}$ & Consumption & Stated & n.a. & SRI \\
\hline $\begin{array}{l}\text { Hafner et al., } \\
2019\end{array}$ & Consumption & Stated & Mixed & SRI \\
\hline \multicolumn{5}{|c|}{ Activating other-regarding preferences (e.g. through framing, appeals) } \\
\hline $\begin{array}{l}\text { Bain et al., } \\
2012 \text {, study } \\
2\end{array}$ & Public & Stated & n.a. & Mixed \\
\hline $\begin{array}{l}\text { Bernauer and } \\
\text { McGrath, } \\
2016, \text { study } \\
1\end{array}$ & $\begin{array}{l}\text { Consumption } \\
+ \text { Public }\end{array}$ & Stated & n.a. & Same \\
\hline $\begin{array}{l}\text { Bernauer and } \\
\text { McGrath, } \\
2016 \text {, study } \\
2\end{array}$ & $\begin{array}{l}\text { Consumption } \\
+ \text { Public }\end{array}$ & Stated & n.a. & Same \\
\hline $\begin{array}{l}\text { de Dominicis } \\
\text { et al., } 2017 \text {, } \\
\text { study } 1\end{array}$ & Consumption & Stated & n.a. & Mixed \\
\hline $\begin{array}{l}\text { de Dominicis } \\
\text { et al., } 2017 \text {, } \\
\text { study } 2\end{array}$ & Consumption & Stated & n.a. & Mixed \\
\hline $\begin{array}{l}\text { de Dominicis } \\
\text { et al., } 2017 \text {, } \\
\text { study } 3\end{array}$ & Consumption & Obs. & n.a. & Mixed \\
\hline $\begin{array}{l}\text { Severson and } \\
\text { Coleman, } \\
2015\end{array}$ & Public & Stated & Yes & Mixed \\
\hline $\begin{array}{l}\text { Evans et al., } \\
\text { 2013, study } \\
1\end{array}$ & Consumption & Obs. & Yes & ORI \\
\hline $\begin{array}{l}\text { Evans et al., } \\
2013 \text {, study } \\
2\end{array}$ & Consumption & Obs. & Yes & ORI \\
\hline $\begin{array}{l}\text { Ferraro and } \\
\text { Price, } 2013\end{array}$ & Consumption & Obs. & Yes & n.a. \\
\hline $\begin{array}{l}\text { Ferraro et al., } \\
2011\end{array}$ & Consumption & Obs. & No & n.a. \\
\hline Gosnell, 2018 & Consumption & Obs. & Mixed & Same \\
\hline $\begin{array}{l}\text { Loureiro and } \\
\text { Lima, } 2019\end{array}$ & Consumption & Obs. & Mixed & n.a. \\
\hline $\begin{array}{l}\text { Ovchinnikova } \\
\text { et al., 2009, } \\
\text { study } 1\end{array}$ & Public & Obs. & Yes & ORI* \\
\hline \multirow{2}{*}{$\begin{array}{l}\text { Ovchinnikova } \\
\text { et al., } 2009 \text {, } \\
\text { study } 2\end{array}$} & Public & Obs. & No & ORI \\
\hline & Public & Stated & No & Mixed \\
\hline
\end{tabular}

Table 2 (continued)

\begin{tabular}{|c|c|c|c|c|}
\hline \multirow[t]{2}{*}{ Study } & \multicolumn{2}{|l|}{ PEB } & \multicolumn{2}{|l|}{ Results } \\
\hline & Type of PEB & $\begin{array}{l}\text { Behavioural } \\
\text { measure }\end{array}$ & $\begin{array}{l}\text { Significant } \\
\text { positive } \\
\text { effect of } \\
\text { other- } \\
\text { regarding } \\
\text { intervention } \\
\text { (ORI) }\end{array}$ & $\begin{array}{l}\text { Greater } \\
\text { behavioural } \\
\text { effect: ORI } \\
\text { vs. self- } \\
\text { regarding } \\
\text { intervention } \\
\text { (SRI) }\end{array}$ \\
\hline \multicolumn{5}{|l|}{$\begin{array}{l}\text { Singh and } \\
\text { Swanson, } \\
2017\end{array}$} \\
\hline $\begin{array}{l}\text { Verplanken } \\
\text { and } \\
\text { Holland, } \\
\text { 2002, study } \\
1\end{array}$ & Consumption & Stated & Yes & n.a. \\
\hline \multicolumn{5}{|c|}{ Raising empathic concern (e.g. through perspective-taking) } \\
\hline $\begin{array}{l}\text { Berenguer, } \\
2007\end{array}$ & Public & Stated & Yes & n.a. \\
\hline $\begin{array}{l}\text { Czap et al., } \\
2012\end{array}$ & Organizational & Obs. & Yes & ORI* \\
\hline $\begin{array}{l}\text { Czap et al., } \\
2015\end{array}$ & Organizational & Obs. & Yes & SRI \\
\hline $\begin{array}{l}\text { Pahl and } \\
\text { Bauer, } 2013\end{array}$ & $\begin{array}{l}\text { Consumption } \\
+ \text { Public }\end{array}$ & Stated, obs. & Yes & n.a. \\
\hline $\begin{array}{l}\text { Pfattheicher } \\
\text { et al., } 2016 \text {, } \\
\text { study } 2\end{array}$ & Consumption & Stated & Yes & n.a. \\
\hline $\begin{array}{l}\text { Shelton and } \\
\text { Rogers, } \\
1981\end{array}$ & $\begin{array}{l}\text { Consumption } \\
+ \text { Public }+ \\
\text { activism }\end{array}$ & Stated & Yes & n.a. \\
\hline \multicolumn{5}{|c|}{ Expanding moral the moral circle (e.g. through re-categorization) } \\
\hline $\begin{array}{l}\text { Bratanova } \\
\text { et al., 2012, } \\
\text { study 2b }\end{array}$ & Public & Stated & Yes & n.a. \\
\hline $\begin{array}{l}\text { Bratanova } \\
\text { et al., 2012, } \\
\text { study 2c }\end{array}$ & Public & Stated & Yes & n.a. \\
\hline $\begin{array}{l}\text { Bratanova } \\
\text { et al., 2012, } \\
\text { study 2d }\end{array}$ & Public & Stated & Yes & n.a. \\
\hline
\end{tabular}

Note: The first column specifies the behaviour type of PEB following Stern (2000)'s classification: Consumption/private-sphere behaviour (consumption), public sphere behaviour (public), behaviour in organizations (organizational) and activism (activism), We indicate whether the behavioural measure was stated or observed (obs.). If results are ambiguous for different subgroups of participants or treatment combinations, we state results as "mixed". For two of the studies (marked with an *), the self-regarding intervention did not point to the benefits of engaging in PEB, but to the benefits of not engaging in PEB (i.e. a trade-off situation).

Induced perspective-taking. A further effective way to address otherregarding preferences and thus promote PEB was by inducing perspective-taking (e.g., through instructions, role reversal or personal requests). Several psychological studies found a positive effect on PEB by giving subjects perspective-taking instructions (along the lines of "try to feel what the other feels") in comparison to providing subjects with control instructions ("try to stay as neutral and objective as possible"). Perspective-taking in these studies was targeted towards entities negatively affected by environmental degradation: other humans (Pahl and Bauer, 2013; Pfattheicher et al., 2016), animals (Shelton and Rogers, 1981; Berenguer, 2007) or plants (Berenguer, 2007). Experimental economic studies on empathy used messages and role reversals that showed a positive effect on conservation choices in a framed lab experiment (Czap et al., 2012) and prevented a drop in PEB when 
financial incentives were taken away (Czap et al., 2015). ${ }^{8}$

Morally relevant re-categorization. Last, a re-categorization of morally relevant information - i.e. an alteration of what is deemed as possessing moral worth - was effective in promoting PEB.. In the studies by Bratanova et al. (2012), a simple change in the instructions (asking participants to either circle entities to which they felt morally obliged or to cross out those to which they did not feel any moral obligation) sufficed to make a significant difference in terms of which entities were considered. This, in turn, had an impact on several PEB variables, namely hypothetical money allocation decisions, policy support and intentions to engage in concrete behaviours. For the study of Bastian et al. (2019), it could be argued that the novel information about the death of crickets also added a new moral dimension to the individual decision to withdraw resources, which might have been the driver for a reduction in resource use.

\subsection{Which types of PEB are promoted by the other-regarding interventions?}

According to Stern (2000), there are four distinct types of PEB: (i) consumption behaviour (e.g. purchasing decisions), (ii) non-activist public sphere behaviour (e.g. policy approval), (iii) behaviour in organizations (e.g. work-related decisions) and (iv) activism (e.g. active involvement in pro-environmental organizations). We hypothesized that addressing other-regarding preferences can increase PEB. Based on the specific operationalization of PEB used as dependent variable in our sample, we can confirm this claim with certainty only for two of the four types of PEB, namely consumption behaviour and non-activist public sphere behaviour. The amount of studies analysing organizational behaviour and activism is insufficient to derive robust conclusions. ${ }^{9}$

Consumption behaviour. Our review suggests that other-regarding interventions can be successful in increasing observed or stated proenvironmental consumption behaviour. Regarding observed behaviour, other-regarding interventions successfully promoted recycling (Evans et al., 2013) as well as (for subgroups) energy saving (Loureiro and Lima, 2019) and switching to paperless billing (Gosnell, 2018). Further, other-regarding interventions triggered a reduction in water use in a field experiment (Ferraro and Price, 2013) and resource consumption in a lab experiment (Bastian et al., 2019). With respect to stated behaviour, other-regarding interventions were able to raise intentions to adopt eco-driving behaviours (Dogan et al., 2014), to help save whales (Shelton and Rogers, 1981), (for a subgroup) to use less bottled water (Bolderdijk et al., 2013b) and to perform PEB more generally (Pahl and Bauer, 2013; Pfattheicher et al., 2016), and increased the likelihood of a (hypothetical) purchase of a more environmentally-friendly TV set (Verplanken and Holland, 2002) or heating technology (Hafner et al., 2019).

Non-activist public sphere behaviour. The other-regarding interventions increased a variety of non-activist public sphere behaviours, mostly measured as (stated) policy support (Bratanova et al., 2012; for a subgroup also Bolderdijk et al., 2013a; Severson and Coleman, 2015). In other studies, positive effects were found on real or hypothetical resource allocation decisions for publicly advocating proenvironmentalism. For example, the other-regarding interventions

\footnotetext{
${ }^{8}$ In addition, Ortiz-Riomalo et al., 2021 study the impact of perspectivetaking on pro-social behaviour in complex socioecological systems such as watersheds. The results of the lab-in-the field experiment demonstrate that when downstream farmers were induced to take the perspective of upstream famers, they were significantly more likely to act pro-socially and helped to redistribute the benefits gained from the resource. This study was not included in the main review since it was publicized after the search date.

9 Activism and behaviour in organizations could be labelled in the literature with more specific terms (e.g., as farmer behaviour or activism) and thus might not have come up with our search terms.
}

increased the stated fund allocation for environmental purposes (Berenguer, 2007; Bratanova et al., 2012) as well as the observed proportion of offsets sold to a conservation NGO instead of to the stock market (Ovchinnikova et al., 2009, study 1). Furthermore, otherregarding interventions increased observed interest in environmental information (more time spent looking at material and more brochures collected - Pahl and Bauer, 2013).

Behaviour in organizations. The evidence base on organizational behaviour is small: the only studies whose dependent variables could possibly be qualified as such were framed lab experiments with nonfarmers simulating tillage decisions (Czap et al., 2012; Czap et al., 2015). ${ }^{10}$ Here, the other-regarding interventions led participants to reduce pollution and harm to the downstream farmers at own cost (observed game decisions).

Activism. We cannot say much about activism since only the study by Shelton and Rogers (1981) operationalized PEB in this way. They found that the other-regarding intervention increased the time participants offered to help addressing envelopes for a local campaign to save whales.

\subsection{Through which channels do the interventions work?}

To understand how other-regarding preferences can be addressed to strengthen PEB, reviewing the experimental findings helps us to identify the underlying mechanisms (i.e. mediators), by which the listed interventions likely triggered an effect on PEB: (i) activating pre-existing other-regarding preferences, and more specifically (ii) raising awareness about adverse consequences on others, (iii) raising empathic concern and thereby altruistic motivation, and (iv) expanding the moral circle. Some of the interventions likely worked through more than one channel at the same time (e.g. giving feedback on behavioural impacts can inform about adverse consequences on others and activate otherregarding preferences).

Activating pre-existing other-regarding preferences. People hold both other-regarding and self-regarding preferences (Fehr and Schmidt, 2006; e.g. Lynne et al., 2016). Several theories postulate that both types of preferences can be activated by contextual factors (Schwartz, 1977; Lindenberg and Steg, 2007; Sagoff, 1988). Two studies in our sample replicated the general finding that stronger other-regarding preferences (measured as biospheric value strength or low selfism) are associated with more PEB (Ovchinnikova et al., 2009; Bolderdijk et al., 2013a). Verplanken and Holland (2002), on the other hand, found that these other-regarding preferences alone had no effect on PEB, they needed to be activated. Direct appeals to these preferences in form of calls for action on behalf of others can be understood as a conscious activation of other-regarding preferences (Gosnell, 2018). However, preference activation also happens unconsciously, e.g. by framing a situation in different ways conveying an implicit reference to either more self- or more other-regarding preferences (cf. Chong and Druckman, 2007). Many of the studies in our sample, particularly the ones using framing techniques or different frames of behavioural feedback, have argued that at least one channel through which their interventions work is preference activation (Bain et al., 2012; Evans et al., 2013; e.g. Dogan et al., 2014; Severson and Coleman, 2015; Hafner et al., 2019; Loureiro and Lima, 2019).

Raising awareness of adverse consequences on others: Behavioural theories on other-regarding behaviour (e.g. Batson's theory of altruism or Stern et al.'s Value-Belief-Norm theory) highlight the importance of

\footnotetext{
10 We note here a field experiment conducted by Czap et al. (2019) that found an increase of enrollment in conservation programs of actual farmers by using empathy messages. However, we excluded this study as the messages also included elements of descriptive social norms, which makes it impossible to say which parts of the letters induced the effect (on a discussion of interactions with social norms see section 4.5).
} 
being aware of adverse consequences on others (Stern et al., 1999) or perceiving their need (Batson, 2011) in order to act upon one's otherregarding preferences. Several of the reviewed interventions conveyed knowledge about adverse consequences on others either as information or as feedback linked to individual behaviour (e.g. environmental and health consequences linked to electricity use - Asensio and Delmas, 2015). The study results also show that learning about adverse consequences is often a necessary, but not a sufficient condition: In Bolderdijk et al. (2013a)'s study, for example, informing study participants about the negative environmental impacts of bottled water only had a positive effect on intentions and policy approval for people with high biospheric values. A similar result is found by the study of Ferraro and Price (2013): after providing households with information about the negative consequences of high water use, a reduction in water consumption was only observed for environmentally conscious consumers. In line with the theories cited above, these findings suggest that learning about the detrimental consequences on others - people and nature - linked to one's behaviour can increase PEB, at least when further conditions are fulfilled (for more details on moderation effect see section 4.5).

Raising empathic concern. ${ }^{11}$ Developing an other-regarding motivation through increased empathic concern is described as a further channel in the reviewed studies. According to Batson (1991), empathic concern means an emotional state congruent with another's well-being. His empathy-altruism hypothesis states that empathic concern results in other-regarding motivations. Taken together with the costs of behaviour, this other-regarding motivation ultimately translates into behaviour. According to Batson's theory, empathic concern emerges from two antecedents: perceiving the other as in need, and valuing the other. Perspective-taking, for example, is frequently discussed in the literature as a technique to increase empathic concern, addressing both of these antecedents, and has shown to be effective in many studies (for a review and also limitations see Batson, 2011). The reviewed studies show that perspective-taking is also successful to foster other-regarding behaviour in the environmental context (e.g., Czap et al., 2012, 2015; Pahl and Bauer, 2013). Successful manipulation checks or pre-studies indicated that this effect on PEB could indeed be induced by increased empathic concern (e.g., Pfattheicher et al., 2016; Berenguer, 2007), which in turn might promote a more favourable attitude towards the entire species (Shelton and Rogers, 1981) or nature as a whole (Berenguer, 2007, in the same direction Sevillano et al., 2013). The studies aimed at increasing empathic concern show that empathic states are not (only) attributable to fixed personality traits and predispositions, but can also be intentionally invoked through interventions.

Expanding the moral circle. Whether nature itself or different species are considered as morally worthy, regardless of the benefits provided to humans, is contested and varies across cultures and belief systems (Pascual et al., 2017). The greater the circle of entities considered as morally worthy - sometimes referred to as the "moral circle" -, the greater is the willingness to protect those within, also at personal cost (Singer, 1981; Crimston et al., 2016). The width of the moral circle has been observed to change over time and thus can also expand (see Crimston et al., 2016 for an overview). One way to intentionally expand the moral circle is by deconstructing existing moral boundaries and recategorizing entities in a way that makes them worthy of moral consideration. The series of experiments by Bratanova et al. (2012) showed that the moral expansion they triggered by subtle interventions, at least for the moment of the experiment, was able to increase different PEB types. The authors concluded that "the moral circle is a common motivational cause of cross-situational pro-environmentalism" (p. 455). Their study indicates that the categorization of what is morally worthy and the associated behavioural response are not stable, but receptive to changes in the situational environment.

\footnotetext{
11 The reviewed studies sometimes also refer to the terms empathy or compassion.
}

4.5. Which factors explain the effect of other-regarding interventions on $P E B$ ?

Our analysis up to here described the results from studies which reported an increase in PEB after the other-regarding intervention. A substantial amount of studies (8 out of 26), however, do not find this effect or report mixed effects performing subgroup analyses. In this respect, our analysis provides insights into moderating factors, i.e. under what conditions and for whom the interventions were effective. While many factors can serve as moderating factors, we focus here on a selection that emerged directly from the analysis.

Activating other-regarding preferences requires that these preferences already exist. Several studies showed that the success of the otherregarding interventions in promoting $\mathrm{PEB}$ was moderated by preexisting preferences (Verplanken and Holland, 2002; Bolderdijk et al., 2013a; de Dominicis et al., 2017; Singh and Swanson, 2017; Loureiro and Lima, 2019). Most studies support the idea of preference congruence: only those individuals who already hold strong other-regarding preferences or for whom the other-regarding preferences are central to their self-concept respond to other-regarding interventions (Verplanken and Holland, 2002; Bolderdijk et al., 2013a; de Dominicis et al., 2017). de Dominicis et al. (2017), for example, found that other-regarding appeals were only effective for altruists while self-regarding appeals were effective both for egoists and altruists. Singh and Swanson (2017) tested different framings and found for the subgroup of political conservatives that the rated importance of climate policies even diminished when they were exposed to the other-regarding frame. This result might be driven by weaker other-regarding preferences of conservatives that several studies report (Sheldon and Nichols, 2009; Zettler et al., 2011; van Lange et al., 2012). These findings are also in line with Batson's theory of altruism, which requires that the perception of others' need must go in hand with valuing them to trigger other-regarding behaviour. Loureiro and Lima (2019), on the other hand, found the strongest impact of their other-regarding intervention among actors with low pre-existing other-regarding preferences. The authors see the level of required cognitive reasoning as an explanation for this difference from previous results: For less conscious decisions, lower other-regarding preferences can be compensated through situational cues, while interventions involving conscious reasoning rely more heavily on pre-existing otherregarding preferences to be successful. In sum, pre-established preferences matter for the effect of other-regarding interventions. Most studies support the proposition that congruence with pre-existing preferences is necessary for interventions to be effective.

Moreover, various studies indicate that the cost structure of a given situation or induced by complementary policies matters for the effectiveness of the other-regarding intervention. In the experiment by Ovchinnikova et al. (2009), price changes largely drove the PEB decision patterns of participants: When behaviour had higher opportunity costs (here when selling offsets on a stock market became relatively more profitable than selling them to a nature conservation agency), the effect of the other-regarding intervention vanished. Similarly, the experiment by Czap et al. (2015) showed that the effect of the other-regarding intervention could be enhanced when financial incentives were added. In the study by Ferraro and Price (2013), water reduction was weaker for below average water users. This could likely be attributed to the relative costliness of reducing an already low and therefore probably efficient resource use. Overall, these findings support the theoretical and empirical claim that relative costs of behaviour in terms of money, time or attention matter for PEB in general as well as for the effectiveness of other-regarding interventions.

Further, the perceived cooperation of others may play an important role for the effectiveness of other-regarding interventions. In line with the general findings on social norms and PEB (Farrow et al., 2017), several studies found other-regarding interventions to be effective only in conjunction with descriptive social norms interventions (Ferraro et al., 2011; Hafner et al., 2019). Descriptive social norms provide 
information on what other people of an associated group do, thereby exerting an influence on individual decisions (Cialdini et al., 1990, a well-known example is the OPOWER study by Allcott, 2011). The combination of both other-regarding and descriptive social norm interventions was most effective in two experiments: Ferraro and Price (2013) added a social comparison in one treatment and thereby increased the effectiveness of the other-regarding appeal; in the study by Hafner et al. (2019), the effectiveness of the other-regarding intervention depended altogether on the additional social norm treatment. From research on social dilemmas, we know many people are conditional cooperators, i.e. they cooperate under the condition that others also cooperate (Fischbacher et al., 2001). The existence (or display) of descriptive social norms decreases hereby the uncertainty about others' behaviour and hence allows for conditional cooperation to take place.

Short-term and subtle interventions are likely to be insignificant amidst strong everyday frames and other powerful determinants of PEB. Contrary to the study by Severson and Coleman (2015), several studies that employed different framings of climate change as an intervention did not find a positive effect on PEB, mostly operationalized as acceptance of mitigation policies (Bain et al., 2012; Bernauer and McGrath, 2016; Singh and Swanson, 2017). The lack of significant results may be explained by interventions being too weak (often short text paragraphs were used to frame the consequences of climate change in a more selfregarding or other-regarding way) in relation to strong everyday frames as portrayed through the media and public discourse (O'Neill et al., 2015). Moreover, political identities tend to be firm and are strongly linked to policy attitudes (Drews and van den Bergh, 2016; Harring et al., 2017). Another aspect that points to the determining role of contextual factors is the fact that the effect of other-regarding interventions seems to be fragile. While most studies analysed only the short-term effects, measured directly after the intervention, Ferraro et al. (2011) examined how the effects of letters with other-regarding appeals to reduce water usage have developed after two years: With time, the positive effect of the other-regarding intervention vanished. ${ }^{12}$ Only when the appeal was combined with the descriptive social norm intervention could the reduction in water usage be maintained. In sum, this suggests that other-regarding interventions do not only need to be strong to overcome competing frames or contextual factors, but also need to be stabilized to have a lasting effect.

\subsection{How do other-regarding interventions compare to self-regarding interventions?}

In this section, we examine the relative effectiveness of otherregarding interventions by comparing their effects to the effects of self-regarding interventions to promote PEB, i.e. interventions aimed at the egoistic motivations of individuals (e.g. incentives or self-regarding appeals). Experiments that employ both intervention types, as complementary treatments or with one being used as the control, may provide us with insights on this matter. The results draw an inconclusive picture of which intervention type is more effective in promoting PEB (see Table 2, column 7) and point to potential side effects of either intervention type.

For situations where PEB creates also potential benefits for the decision-maker herself, six experimental studies found greater effects for the other-regarding intervention (Bolderdijk et al., 2013b; Czap et al., 2012; Evans et al., 2013, study 1,2; Asensio and Delmas, 2015; Ovchinnikova et al., 2009, study1,2) and three a greater effect for the self-regarding intervention (Czap et al., 2015; Hafner et al., 2017, 2019). Four experiments showed equal (or equally missing) effects of both intervention types (Dogan et al., 2014; Bernauer and McGrath, 2016, study 1,2; Gosnell, 2018) and six found mixed effects depending on subgroup characteristics (Bain et al., 2012; Severson and Coleman, 2015; de Dominicis et al., 2017, study 1-3; Singh and Swanson, 2017). Interventions differ in the type of self-regarding arguments used (e.g. money, safety, convenience) and their strength (e.g. the amount of money implied by the argument or opportunity costs of the target PEB), which may explain the variation in the effectiveness of the interventions. Bolderdijk et al. (2013a) is the only study that directly compared different types of self-regarding arguments: The authors found no statistically significant differences in behaviour when PEB was aimed to be induced either with arguments emphasizing financial savings or safety gains. While the result should be taken with caution due to the small sample size, it is conceivable that individuals in general respond differently to the different types of self-regarding arguments, according to their personal preferences and/or financial resources. As for the strength of the argument, the financial effects of eco-driving, for instance, are quite small (several euros per month - Dogan et al., 2014) compared to the monthly savings of choosing an initially expensive heat pump (several dozens of euros per month - Hafner et al., 2017, 2019). In both studies, the intervention informed participants about the saving potential. The cost differences, in addition to the differences in the sample population, likely explain the varying effectiveness of the two self-regarding interventions. Likewise, other-regarding interventions vary: the studies by Hafner et al. $(2017,2019)$, which found the selfregarding intervention to be more effective, give information about reduced $\mathrm{CO}_{2}$ emissions of certain behaviours. For many people it is likely difficult to assess how meaningful these savings are. Asensio and Delmas (2015), on contrast, translate these numbers into more specific environmental and health effects and find stronger effects of the otherregarding intervention. Hence, the specifics of the intervention determine their relative effectiveness and may explain most of the aforementioned differences in the comparison of self- and other-regarding interventions.

Beyond direct comparisons of effectiveness, (unintended) side effects of both intervention types, which may stem from the different motivational approaches, are worth considering. For instance, motivating people for PEB with other-regarding reasons has the potential to create positive spillovers to other behavioural domains (Thøgersen and Crompton, 2009; Truelove et al., 2014). In line with this literature, Evans et al. (2013) showed that the presentation of statements highlighting other-regarding reasons for car-sharing, such as less pollution, led to positive effects in other environmental domains. In contrast, the authors did not find such spillover effects when participants read statements describing self-regarding reasons, such as cost savings. Likely, this result is explained by the different preference types that were activated by the statements: When the promoted motivation for PEB is other-regarding, it can be transferred to other PEBs, whereas when selfregarding preferences are activated, other PEBs must also be beneficial, following this logic, in order to be performed. Related to this are the potential crowding effects of external interventions that focus on addressing actors' self-interest to motivate behaviour, usually by changing the material conditions in a decision situation. If PEB is at least partly motivated on basis of other-regarding concerns, then introducing self-regarding reasons to motivate pro-environmental action can have detrimental effects on the original motivation to act pro-

\footnotetext{
12 The immediate effect was analysed by Ferraro and Price (2013). The followup paper was published before the initial study.
} 
environmentally (Frey and Stutzer, 2006; Rode et al., 2015) and may induce a more self-regarding mindset. ${ }^{13}$ The results of Bolderdijk et al. (2013b) point into this direction, the economic appeal ("Care for your finances? Get a free tyre check") significantly reduced PEB, compared to control. Another two studies found negative effects of priming a selfregarding mindset in trade-off situations where personal benefit stood in contrast to positive effects for the environment or other people. After priming people with self-interested thinking (e.g. by framing the game description), the study participants reduced their willingness to sell carbon offsets to a nature conservation agency (instead of on a stock market - Ovchinnikova et al., 2009, study 2) or to put land under conservation tillage (Czap et al., 2012). Just as other-regarding preferences can be activated, leading to more other-regarding behaviour (in some instances), self-regarding preferences can be activated as well, bringing forward more self-regarding behaviour.

In terms of combining self- and other-regarding interventions, results indicate a potential for both positive and negative interaction effects. Czap et al. (2015) found an amplified effect of combining financial incentives and empathy messages in their framed lab experiment on farmers' conservation behaviour. They also found that the otherregarding intervention prevented a drop in conservation practice when pecuniary incentives were taken away. Their study result seems to stand in opposition to the detrimental effect of a combination reported by Evans et al. (2013): In their study, combining self-regarding reasons for PEB with other-regarding reasons eliminated the positive spillover on another PEB that occurred when only giving other-regarding reasons. One explanation of these seemingly contrary results may be the different types of self-regarding interventions: in Czap et al. (2015) the payoff structure was modified to make PEB less costly while in Evans et al. (2013) only pre-existing features of the situation were emphasized, possibly activating conflicting preferences that may explain the detrimental effects.

Based on these mixed results, which can partly be explained by the variety of interventions and their varying strengths, we are not able to derive a uniform conclusion on whether self-regarding or otherregarding interventions are more effective in promoting PEB. We find some evidence in our sample that motivating PEB with self-regarding reasons can even lead to less $\mathrm{PEB}$, possibly by inducing a more selfregarding mindset. Motivating $\mathrm{PEB}$ with other-regarding reasons may, on the other side, have positive spillover effects to other PEBs. While the intervention types can counteract each other in some instances, they can also act as complements to strengthen PEB.

\section{Conclusion and implications}

Our review of the experimental studies suggests that addressing other-regarding preferences can in many, but not all cases be successful in promoting different types of PEB. Hence, we confirm the causal link suggested by various theories of other-regarding behaviour and proposed by correlational studies on other-regarding preferences and PEB. The success of these interventions, however, hinges on contextual factors such as cost structures, pre-existing preferences and the perceived cooperation of others, which explains partly the divergent results in some of the studies. In comparison to self-regarding interventions, it is

\footnotetext{
13 Following the findings from the crowding literature, intrinsic motivation to act pro-environmentally is strengthened if the externally provided reasons support, acknowledge and complement the pre-existing motivation to act proenvironmentally. If, however, the externally provided self-regarding reasons are perceived as substitutes for the original motivation to act (Lepper et al., 1973), and they deprive the possibility to (self)signal one's pro-social motives (Bénabou and Tirole, 2006) and/or reduce the degree of self-determination (Frey and Jegen, 2001), then it is likely that the original intrinsic motivation to act pro-environmentally is crowded out. For a review on crowding effects of environmental policies see Rode et al. (2015).
}

not clear which type of intervention is more effective per se, yet the other-regarding interventions yielded two advantages: They did not entail any negative side effects from activating a more self-regarding mindset and they were able to create positive spillovers to other environmental behaviours.

Regarding the question how other-regarding preferences can be addressed in order to promote PEB, we can summarize that effective interventions work by raising awareness about adverse consequences on others, activating other-regarding preferences, raising empathic concern or expanding our moral circle. Hence, interventions unfold their effects based on existing other-regarding preferences, or they actively cultivate or expand them. Table 3 provides an overview of our results.

\subsection{Implications for future research}

From the review, theoretical, methodological and more general implications can be drawn for future research.

Theoretically, the economic concept of other-regarding preferences could be enriched by more psychological insights about how otherregarding motivations emerge or develop. The dominant economic approach to model behaviour is still one of a single abstract motivation aimed at increasing own utility. Even when the utility function is widened to include aspects of others' well-being, the general logic of decision-making does not change. The psychological literature, however, shows that multiple and distinct value dimensions motivate behaviour that cannot be reduced to a single abstract driver of behaviour. The tripartite structure of environmental concern - biospheric, altruistic and egoistic concern (Stern et al., 1999; Schultz, 2001) could be taken as a starting point to develop more complex economic theories of multiple motive systems or advance existing ones (e.g., Bosworth et al., 2016; Lynne et al., 2016) to make them applicable in the environmental context.

With respect to interventions aimed at promoting PEB by addressing other-regarding preferences, the reviewed findings reveal that many interventions only work when several conditions are met (e.g. when people know about adverse consequences on others and value them). In addition, two studies indicated that the behavioural effects can be ensured or strengthened when the other-regarding intervention is combined with other sorts of interventions, such as e.g. descriptive social norm interventions. Another possibility could be to combine different kinds of other-regarding interventions in order to meet the aforementioned conditions. Future research may further investigate the combination possibilities of interventions. Beneficial could be, for example, joint interventions which also aim at raising awareness about the behavioural consequences and/or evoke empathic concern. Generally, we assume that such combinations have the potential to boost the

Table 3

Summary of main findings of the review.

\begin{tabular}{ll}
\hline $\begin{array}{l}\text { Successful other-regarding } \\
\text { interventions }\end{array}$ & - Information or feedback on behavioural \\
& consequences on others \\
& - Issue framing/priming \\
& - Appeals to other-regarding preferences \\
& - Induced perspective-taking \\
& - Morally relevant re-categorization \\
Channels & - Activating other-regarding preferences \\
& - Raising awareness of adverse \\
& - Raising empathic concern \\
& - Expanding the moral circle \\
Promoted PEB types & - Consumption behaviour \\
& - Non-activist public sphere behaviour \\
Moderating factors for intervention & - Pre-existing other-regarding preferences \\
effectiveness (selection) & - Cost structure \\
Possible positive side effects of other- & - Perceived cooperation of others \\
regarding interventions & - Lower risk of having detrimental effects \\
\hline
\end{tabular}


effect on PEB, as they may be able to activate other-regarding preferences on the cognitive and affective level. However, if individuals will feel controlled by the interventions (control aversion - Falk and Kosfeld, 2006) or the intervention combination poses too excessive demands on the human ability to process information (bounded rationality - Simon, 1972), then it can be expected that combinations will rather dilute the effect.

Moreover, future research may expand the target group whose wellbeing shall be taken into account. For example, we argued in section 2 that also future generations can count as others. We believe that it will be an interesting task for future research to systematically examine how behavioural effects change when the well-being of future generations is considered instead of the well-being of currently living others. For now, we can only speculate about what differences in behaviour might emerge. Psychological studies suggest that the well-being of objects perceived as more distant are given less weight in the decision-making process (e.g. Spence et al., 2012). Thus, for the behavioural effects it seems to be crucial how decision-makers relate to those future others (e. g. imagine the well-being of your grand-granddaughter vs. of a generic future other).

With regard to the conceptualization and operationalization of $P E B$, we think that including acceptance of policies is an important type of PEB that is too often neglected in experimental designs. Measures of consumption behaviour are the most prevalent both in the economic and psychological literature. Acceptance of policies, in contrast, is almost exclusively examined in the literature on framing effects related to climate change, which is informed by the social and political sciences. Hence, many economic and psychological studies could be enriched by widening their scope of what they consider as PEB by including acceptance of policies. ${ }^{14}$ In a democracy, restrictions imposed by public policy have to be legitimized by a majority of people approving them. Understanding the conditions under which individuals are willing to accept future costs and restrictions originating from public policies is thus an important research aim. This could also help counter a reproach made to the behavioural sciences, namely that it would shift the attention from structural changes to the individual and their consumption decisions (a point raised e.g. in Straßheim and Beck, 2019).

Lastly, linking different disciplines or dealing with genuinely interdisciplinary research bears the chance to learn from the strengths of each discipline. While economists may refine their experimental methods by e. g. applying more manipulation checks, psychologists could, for example, incorporate more resource-based (observable) measures of behaviour to make the study results more applicable for real life behaviour. The social and political sciences have much to offer when it comes to theorizing care or solidarity - other concepts related to other-regarding preferences-, yet as they usually do not use experimental methods, these concepts are widely absent in the experimental literature and thus also in the studies we reviewed. At the same time, these disciplines could widen their methodologic portfolio with experiments. It remains a challenge for science to allow for such learning opportunities while at the same time not giving up the merits of disciplinary specialization.

\footnotetext{
14 Acceptance of policies is often dismissed in the economics discourse as a stated preference indicator that does not entail real costs. While it is certainly true that people tend to state more pro-environmental preferences than they translate into action (e.g., Diekmann and Preisendörfer, 2003), this does not mean these indicators are worthless. In fact, accepting policies can, in many respects, only be a stated preference as voting decisions cannot be elicited (for good reasons). Furthermore, there are no reasons to assume why people would generally state that they would accept a certain policy when, in fact, they do not. In contrast, a gap between intentions and behaviour is very plausible for consumption behaviour as people have to act on their intentions themselves, which implies personal efforts and immediate costs and thus leads to reduced implementation. Such gap does not exist when anonymously stating (dis) approval of restrictions or costs imposed by policies.
}

\subsection{Institutional implications}

When thinking about the institutional implications of our results, the nature and the methodological limitations of the reviewed research have to be considered. First, most of the experiments were short-term (both with respect to the intervention as well as the measurement of PEB) and they did not have representative samples. Second, the study results are more informative on potential channels than concrete interventions that could work to promote PEB by addressing other-regarding preferences. Even if certain interventions in the experiments prove to be effective in increasing PEB, implementing them as policies demands further justification: policy legitimacy is established through the approval of citizens or their elected representatives within democratically organized societies (cf. Lepenies and Malecka, 2019). Moreover, distributional impacts as well as unintended consequences must be considered in the policy design process. Hence, we will discuss in the following some broader political and institutional implications instead of concrete policy instruments.

From the experiments, we can conclude that the orientation towards self and others is indeed variable and matters for PEB. When designing policies to tackle environmental problems this linkage should be thoughtfully considered. The experimental results provide us with knowledge about channels and exemplary interventions. Moreover, many of the results show that various factors such as valuing the other (s), i.e. having pre-established other-regarding preferences, and learning about the adverse consequences on them, have to come together for other-regarding preferences to play out in the decision-making (e.g. Bolderdijk et al., 2013a). Another caveat is the fragility of effects as shown by the experimental interventions (Ferraro et al., 2011; Ferraro and Price, 2013). Rather than an incoherent bundle of policies and shortterm interventions counteracting each other, coherent and multi-faceted policy environments are needed to enable and amplify positive policy effects and stabilize them for the long run.

Further, policy environments can intentionally foster a willingness to cooperate. Allowing for conditional cooperation to take place can likely boost such a willingness. Various studies in our sample showed that cooperative decisions increased and lasted longer when people thought that (many) others were doing the same. While some certainty about others' behaviour is granted by (changing) social norms in favour of PEB (Nyborg, 2018), policies that go beyond voluntary compliance (e.g. regulatory approaches) are probably needed to signal that the burden of environmental protection is shared by many. At the same time, policy makers must also be careful that policy environments do not unintentionally decrease such a willingness to cooperate. Hence, creating the conditions for a society that is willing to accept other-regarding policies, even at own costs or discomfort becomes an important policy objective. In other words, it means enabling a society to collectively orient itself towards the ideal of "environmental citizenship", which demands that people in their role as citizens take responsibility for their natural and social environment (Dobson and Bell, 2006). This also implies a willingness to give up current privileges in terms of wealth and access to resources. Cultivating such a willingness will likely be a long-term cultural process linked to the question of how we want to relate to each other (cf. Adamczak, 2017).

In line with the literature, our findings show that (opportunity) costs of the associated behaviour or policy approval evidently matter. This finding is well-established in research (e.g. economic price theory or psychological low-cost hypothesis). Thus, reducing the costs of PEB for the individual, which means to make the behaviour easy and cheap so people can act in line with their other-regarding preferences, becomes a core political task. But, caution is needed. Alterations of costs structures often come in the form of financial incentives and these can shift focus on monetary terms strongly associated with self-regarding preferences (Gneezy and Rustichini, 2000; Bowles, 2008). Moreover, it is important that policy instruments do not encourage token actions that may actually have degrading net effects on the environmental quality, e.g., when 
low-cost and low-impact PEBs are promoted, which then license other harmful behaviours or end up to be one-off actions only (Grolleau et al., 2017). The political challenge is therefore to reduce costs and/or to increase benefits of PEB without making price incentives the main or only motivation for action.

Moreover, the reviewed studies indicate that pre-established preferences matter for the overall level of PEB as well as for the effectiveness of interventions. How the process of preference formation in a society takes place, for instance within the education system, thus becomes an important focal point, querying a critical reflection about which preferences are cultivated therein. Generally, preferences can be activated, but are stable in the short-term. In the long-run, however, they can change and are specific to socialization and culture (Bowles, 1998). This endogeneity is important from a political perspective and calls for a critical examination of our thinking patterns, institutions and disciplinary models: Which values and preferences do they capture, support and help to maintain? Possibly, replacing our paradigmatic image of human behaviour, homo oeconomicus, which remains to be the basis of many analyses and consequent political decisions, by a more cooperative human image like the homo cooperativus (Rogall, 2002) or homo sustinens (Siebenhüner, 2001) could help to anchor a more otherregarding orientation of human decision-making.

Beyond that, distributional aspects must be considered. If otherregarding appeals or similar interventions are institutionalized as an environmental policy approach, people already holding strong otherregarding preferences will likely respond while people holding strong self-regarding preferences will likely not. This bears the risk of shifting the (cost) burden of solving environmental problems from the latter to the former. Such unintended distributional impacts need to be considered when designing policies aimed at promoting PEB.

Rather than concluding that political instruments are needed to "make" people more other-regarding, the consequent political question is a more general one: How can institutions be designed in such a way that allows people to care about others in their decision-making, to develop empathic concern, to learn about adverse consequences on others and to consider them as morally worthy? How can institutions and instruments be crafted considering that they can activate either more self-regarding or more other-regarding preferences and how can this activation be stabilized to be effective over time? Direct encounters with people providing the possibility to exchange experiences and perspectives, an inclusive morality and the normalization of otherregarding thought patterns could set impulses in this direction. Fully answering these questions is way beyond the scope of this article, but we hope to have provided an interesting starting point for discussion.

\section{Declaration of Competing Interest}

The authors declare that they have no known competing financial interests or personal relationships that could have appeared to influence the work reported in this paper.

\section{Acknowledgements}

We thank Stefanie Engel, Juan Felipe Ortiz-Riomalo, Ioana Adrian Branga-Peicu, and Maria Angelica Lopez Ardila as well as the two anonymous reviewers for their valuable comments on earlier versions of this manuscript. Moreover, we gratefully acknowledge the funding and support for this research has been received by the Heinrich-Böll-Foundation and the Alexander von Humboldt-Foundation in the framework of the Alexander von Humboldt-Professorship held by Prof. Stefanie Engel, endowed by the German Federal Ministry of Education and Research.

\section{Appendix}

Table A1

Overview of studies in our sample.

\begin{tabular}{|c|c|c|c|c|}
\hline Study & Specifications & Intervention $^{\mathrm{a}}$ & PEB & $\begin{array}{l}\text { Significant effect of other- } \\
\text { regarding intervention }^{\text {b }}\end{array}$ \\
\hline $\begin{array}{l}\text { Asensio and Delmas, } \\
2015\end{array}$ & $\begin{array}{l}\text { Field-experiment with } 118 \\
\text { residences in the U.S. }\end{array}$ & $\begin{array}{l}\text { Feedback on energy consumption in kwh } \\
\text { linked to (i) reduction in air pollution and health } \\
\text { risks vs. (ii) monetary savings vs. (iii) control }\end{array}$ & $\begin{array}{l}\text { Energy consumption over } 8 \text { months, } \\
\text { measured at appliance level }\end{array}$ & Yes* \\
\hline $\begin{array}{l}\text { Bain et al., } 2012 \\
\quad \text { (study 2) }\end{array}$ & $\begin{array}{l}\text { Online experiment with } \\
347 \text { climate change } \\
\text { deniers in the U.S. }\end{array}$ & $\begin{array}{l}\text { Different frames to reduce carbon emissions: } \\
\text { (i) reduce risks on nature, animals and humans } \\
\text { ('real frame' - they use as control); (ii) good } \\
\text { society ('warmth frame'); (iii) economic } \\
\text { benefits and prosperous society ('development } \\
\text { frame') }\end{array}$ & $\begin{array}{l}\text { Environmental citizenship intentions } \\
\text { (e.g. intentions to vote for- } \\
\text { environmental candidates, sign } \\
\text { petitions supporting environmental } \\
\text { protection) }\end{array}$ & Mixed* \\
\hline Bastian et al., 2019 & $\begin{array}{l}\text { Lab experiments with } 149 \\
\text { student participants }\end{array}$ & $\begin{array}{l}\text { Additional information that crickets die if } \\
\text { resource is depleted vs. control }\end{array}$ & $\begin{array}{l}\text { Points taken from resource dilemma } \\
\text { game }\end{array}$ & Yes \\
\hline Berenguer, 2007 & $\begin{array}{l}\text { Lab experiment with } 60 \\
\text { students in Spain }\end{array}$ & $\begin{array}{l}\text { Instructions (perspective-taking vs. stay } \\
\text { neutral) X Object (bird vs. tree) }\end{array}$ & $\begin{array}{l}\text { Attitudes; } \\
\text { Fund allocation recommendation to } \\
\text { student council }\end{array}$ & Yes \\
\hline $\begin{array}{l}\text { Bernauer and } \\
\text { McGrath, } 2016\end{array}$ & $\begin{array}{l}\text { Online experiments with } \\
1675 \text { participants in U.S. }\end{array}$ & $\begin{array}{l}\text { Study 1: like Bain et al., 2012; study } 2 \text { : } \\
\text { alteration with health benefits }\end{array}$ & $\begin{array}{l}\text { DV1: Policy attitudes regarding } \\
\text { climate change mitigation; DV2: } \\
\text { Behavioural change intentions; DV3: } \\
\text { Environmental citizenship intentions }\end{array}$ & No* \\
\hline $\begin{array}{r}\text { Bolderdijk et al., } \\
\text { 2013a (study 3) }\end{array}$ & $\begin{array}{l}\text { Field study at a petrol } \\
\text { station in the U.S. with an } \\
\text { estimated number of } 75.8 \\
\text { customers }\end{array}$ & $\begin{array}{l}\text { Four different signs at petrol station to get free } \\
\text { tire check (e.g. "Care about the environment?" } \\
\text { vs. "Care about your finances?") }\end{array}$ & $\begin{array}{l}\text { Number of coupons taken during } \\
\text { period of } 22 \text { days }\end{array}$ & No \\
\hline $\begin{array}{l}\text { Bolderdijk et al., } \\
\text { 2013b }\end{array}$ & $\begin{array}{l}\text { Online experiment with } \\
192 \text { participants in the } \\
\text { Netherlands }\end{array}$ & $\begin{array}{l}\text { Move about the negative impact of bottled } \\
\text { water vs. unrelated movie }\end{array}$ & $\begin{array}{l}\text { DV1: Acceptance of policies; DV2: } \\
\text { Beliefs and intentions regarding use of } \\
\text { bottled water }\end{array}$ & $\begin{array}{l}\text { Mixed (only for people high on } \\
\text { biospherism) }\end{array}$ \\
\hline $\begin{array}{l}\text { Bratanova et al., } \\
2012\end{array}$ & $\begin{array}{l}\text { Lab experiments with } 189 \\
\text { students in Belgium }\end{array}$ & Manipulation of moral circle size & $\begin{array}{l}\text { Study 1: Moral concern } \\
\text { Study 2: Money allocated for carbon } \\
\text { offsetting } \\
\text { Donated money } \\
\text { Study 3: Support for policies aimed at }\end{array}$ & Yes \\
\hline
\end{tabular}


Table A1 (continued)

\begin{tabular}{|c|c|c|c|c|}
\hline Study & Specifications & Intervention $^{\mathrm{a}}$ & PEB & $\begin{array}{l}\text { Significant effect of other- } \\
\text { regarding intervention }^{\text {b }}\end{array}$ \\
\hline & & & $\begin{array}{l}\text { reducing environmental pollution } \\
\text { Study 4: Intentions to engage in PEB }\end{array}$ & \\
\hline Czap et al., 2012 & $\begin{array}{l}\text { Framed lab experiment } \\
\text { with } 216 \text { students in the } \mathrm{U} \text {. } \\
\text { S. }\end{array}$ & $\begin{array}{l}\text { Different framings of Upstream Farmer/ } \\
\text { Downstream Water User Game: Empathy vs. } \\
\text { Self-interest vs. control }\end{array}$ & $\begin{array}{l}\text { Amount of acres put under } \\
\text { conservation tillage by Upstream } \\
\text { Farmers }\end{array}$ & Yes \\
\hline Czap et al., 2015 & $\begin{array}{l}\text { Lab experiment with } 400 \\
\text { participants in the U.S. }\end{array}$ & $\begin{array}{l}\text { Upstream Farmer/Downstream Water User } \\
\text { Game with empathy messages vs. financial } \\
\text { subsidy }\end{array}$ & $\begin{array}{l}\text { Amount of acres put under } \\
\text { conservation tillage by Upstream } \\
\text { Farmers }\end{array}$ & Yes \\
\hline $\begin{array}{l}\text { de Dominicis et al., } \\
2017 \text { (studies } 2 \text { and } \\
\text { 3) }\end{array}$ & $\begin{array}{l}\text { Lab experiments with } 425 \\
\text { students in the U.S. }\end{array}$ & $\begin{array}{l}\text { Environmental concern manipulation (other- } \\
\text { regarding vs. self-regarding) X value frame } \\
\text { (other-regarding vs. self-regarding frames for } \\
\text { PEB) }\end{array}$ & $\begin{array}{l}\text { Study } 1 \text { and study } 2 \text { : Intentions to } \\
\text { engage in PEB (conserve energy, use } \\
\text { public transport); study 3: sign up for } \\
\text { a beach clean-up event }\end{array}$ & $\begin{array}{l}\text { Mixed (only for those high in } \\
\text { environmental concern } \\
\text { treatment, no for those low in } \\
\text { environmental concern } \\
\text { treatment) }\end{array}$ \\
\hline Dogan et al., 2014 & $\begin{array}{l}\text { Online experiment with } \\
\text { representative sample of } \\
350 \text { participants in the } \\
\text { Netherlands }\end{array}$ & $\begin{array}{l}\text { Different feedback frames for eco-driving: (i) } \\
\text { environmental, (ii) financial, (iii) control }\end{array}$ & $\begin{array}{l}\text { DV1: worthiness of eco-driving } \\
\text { behaviours; DV2: intentions for eco- } \\
\text { driving }\end{array}$ & DV1: No, DV2: Yes \\
\hline Evans et al., 2013 & $\begin{array}{l}\text { Lab experiments with } 130 \\
\text { participants from } \\
\text { University participant } \\
\text { pool in the U.K. }\end{array}$ & $\begin{array}{l}\text { Information about car-sharing: environmental } \\
\text { benefits vs. financial benefits vs. control (first } \\
\text { experiment involved some filler tasks on } \\
\text { personality) }\end{array}$ & $\begin{array}{l}\text { DV1: Use of recycling bin; DV2: use of } \\
\text { scrap paper; in study } 1 \text { also DV3: } \\
\text { choice of energy savings mode on } \\
\text { computer }\end{array}$ & DV1: Yes, DV2: No; DV3: No \\
\hline $\begin{array}{l}\text { Ferraro and Price, } \\
2013\end{array}$ & $\begin{array}{l}\text { Field experiment with } \\
>100.000 \text { water } \\
\text { customers in the U.S. }\end{array}$ & $\begin{array}{l}\text { Letters with (i) technical advice (TA) to save } \\
\text { water, (ii) TA+ appeal to other-regard including } \\
\text { information about adverse consequences (OR), } \\
\text { (iii) TA + OR + descriptive norm of others } \\
\text { behaviour, (iv) control }\end{array}$ & Reduction in water use in 2007 & Yes \\
\hline Ferraro et al., 2011 & $\begin{array}{l}\text { Experiment from Ferraro } \\
\text { and Price, } 2013\end{array}$ & See above. & Reduction in water use in $2007-2009$ & No \\
\hline Gosnell, 2018 & $\begin{array}{l}\text { Field experiment with } \\
36,810 \text { customers of a } \\
\text { renewable energy supplier } \\
\text { in the U.K. }\end{array}$ & $\begin{array}{l}\text { Letters with information about online billing: } \\
\text { (i) environmental benefits; (ii) appeal to } \\
\text { environmental identity; (iii) own advantages }\end{array}$ & Take up rate for online billing & $\begin{array}{l}\text { No for i. and mixed for ii. (only } \\
\text { for those not holding a } \\
\text { doctorate degree) }\end{array}$ \\
\hline Hafner et al., 2017 & $\begin{array}{l}\text { Online study with } 493 \\
\text { participants in the U.K. }\end{array}$ & $\begin{array}{l}\text { Feedback frame for different energy } \\
\text { technologies (environmental vs. financial) X } \\
\text { different messengers; control }\end{array}$ & $\begin{array}{l}\text { DV1: Likelihood of selecting the } \\
\text { 'green' (and more expensive) } \\
\text { technology, DV2: real-life adoption } \\
\text { intentions }\end{array}$ & No* \\
\hline Hafner et al., 2019 & $\begin{array}{l}\text { Online study with } 599 \\
\text { participants in the U.K. }\end{array}$ & $\begin{array}{l}\text { Feedback frame for different energy } \\
\text { technologies (environmental vs. financial) X } \\
\text { different descriptive norms; control }\end{array}$ & $\begin{array}{l}\text { DV1: Likelihood of selecting the } \\
\text { 'green' (and more expensive) } \\
\text { technology, DV2: real-life adoption } \\
\text { intentions }\end{array}$ & $\begin{array}{l}\text { DV1: Yes only in conjunction } \\
\text { with descriptive norms; DV2: } \\
\text { No }\end{array}$ \\
\hline $\begin{array}{l}\text { Loureiro and Lima, } \\
2019\end{array}$ & $\begin{array}{l}\text { Lab experiment with } 118 \\
\text { students in Portugal }\end{array}$ & $\begin{array}{l}\text { Conceptual priming with (i) altruism, (ii) } \\
\text { environmentalism, control }\end{array}$ & $\begin{array}{l}\text { DV1: observed PEB (e.g. turn out light } \\
\text { when leaving); DV2: intentions on } \\
\text { energy savings }\end{array}$ & $\begin{array}{l}\text { Mixed (only for those low on } \\
\text { altruistic values) }\end{array}$ \\
\hline $\begin{array}{l}\text { Ovchinnikova et al., } \\
2009\end{array}$ & $\begin{array}{l}\text { Lab experiments with } 138 \\
\text { students in the U.S. }\end{array}$ & $\begin{array}{l}\text { Other-regarding vs. self-regarding priming vs. } \\
\text { control (different price increases in two } \\
\text { studies) }\end{array}$ & $\begin{array}{l}\text { Proportion of offsets sold to } \\
\text { conservation agency instead of stock } \\
\text { market, with price differential } \\
\text { increasing in each round }\end{array}$ & Study 1: Yes; study 2: No \\
\hline $\begin{array}{l}\text { Pahl and Bauer, } \\
2013\end{array}$ & $\begin{array}{l}\text { Lab experiment with } 83 \\
\text { students in Germany }\end{array}$ & $\begin{array}{l}\text { Perspective-taking instructions vs. stay neutral } \\
\text { instructions linked to narrative of a future } \\
\text { person negatively affected by environmental } \\
\text { degradation vs. control: no narrative }\end{array}$ & $\begin{array}{l}\text { DV1: PEB intentions; DV2: observed } \\
\text { time spent looking at PE information } \\
\text { material; Dv3: observed number of PE } \\
\text { brochures picked up }\end{array}$ & Yes \\
\hline $\begin{array}{l}\text { Pfattheicher, } \\
\text { Sassnenrath, } \\
\text { Schindler, } 2016 \\
\text { (study 2) }\end{array}$ & $\begin{array}{l}\text { Lab experiment with } 94 \\
\text { students in Germany }\end{array}$ & $\begin{array}{l}\text { Perspective-taking instructions vs. stay neutral } \\
\text { instructions }\end{array}$ & PEB intentions & Yes \\
\hline $\begin{array}{l}\text { Severson and } \\
\text { Coleman, } 2015\end{array}$ & $\begin{array}{l}\text { Online experiment with } \\
360 \text { participants in the } \mathrm{U} \text {. } \\
\mathrm{S} \text {. }\end{array}$ & $\begin{array}{l}6 \text { different framings of climate change: } \\
\text { deontological moral (i: secular; ii: religious); } \\
\text { empirical-scientific; economic (iii: economic } \\
\text { equity); control }\end{array}$ & $\begin{array}{l}\text { Policy support for } 10 \text { regulatory } \\
\text { policies to address climate change }\end{array}$ & Yes for i. and iii.; No for .ii. \\
\hline $\begin{array}{l}\text { Shelton and Rogers, } \\
1981\end{array}$ & $\begin{array}{l}\text { Lab experiment with } 118 \\
\text { students in the U.S. }\end{array}$ & $\begin{array}{l}\text { Watching documentary with instructions ( } i \text { : } \\
\text { perspective-taking vs. stay neutral) X level of } \\
\text { noxiousness (ii. high vs. low) X efficacy of } \\
\text { coping response (high vs. low) }\end{array}$ & $\begin{array}{l}\text { DV1: PE intentions; DV2: allocation of } \\
\text { volunteering time; merged to one } \\
\text { index }\end{array}$ & Yes for i. and ii. \\
\hline $\begin{array}{l}\text { Singh and Swanson, } \\
2017\end{array}$ & $\begin{array}{l}\text { Online experiment with } \\
1053 \text { participants in the } U \text {. } \\
\text { S. }\end{array}$ & $\begin{array}{l}\text { Framing climate change as human rights issue } \\
\text { vs. national security issue vs. scientific } \\
\text { consensus on climate change; control }\end{array}$ & $\begin{array}{l}\text { Absolute and relative importance of } \\
\text { climate change policy }\end{array}$ & No \\
\hline $\begin{array}{l}\text { Verplanken and } \\
\text { Holland, } 2002 \\
\text { (study 1) }\end{array}$ & $\begin{array}{l}\text { Lab experiment with } 40 \\
\text { students in the } \\
\text { Netherlands }\end{array}$ & Priming: environmental values vs. no & $\begin{array}{l}\text { Choice of TV sets with better } \\
\text { environmental attributes in consumer } \\
\text { choice task }\end{array}$ & Yes \\
\hline
\end{tabular}

${ }^{\text {a }}$ Other-regarding intervention in italics.

b Compared to control, * if compared to the self-regarding intervention when the study had no neutral control condition. 


\section{References*}

Adamczak, B., 2017. Beziehungsweise Revolution: 1917, 1968 und kommende. Suhrkamp, Berlin.

Allcott, H., 2011. Social norms and energy conservation. J. Public Econ. 95 (9-10), 1082-1095. https://doi.org/10.1016/j.jpubeco.2011.03.003.

Asensio, O.I., Delmas, M.A., 2015. Nonprice incentives and energy conservation. Proc. Natl. Acad. Sci. U. S. A. 112 (6), E510-E515. https://doi.org/10.1073/ pnas.1401880112.

Awad, Edmond, Dsouza, Sohan, Kim, Richard, Schulz, Jonathan, Henrich, Joseph, Shariff, Azim, et al., 2018. The moral machine experiment. Nature 563 (7729). https://doi.org/10.1038/s41586-018-0637-6. S. 59-64.

Bain, P.G., Hornsey, M.J., Bongiorno, R., Jeffries, C., 2012. Promoting pro-environmental action in climate change deniers. Nature Clim Change 2 (8), 600-603. https://doi. org/10.1038/nclimate1532.

Bastian, B., Brewer, M., Duffy, J., van Lange, P.A.M., 2019. From cash to crickets: the non-monetary value of a resource can promote human cooperation. J. Environ. Psychol. 61, 10-19. https://doi.org/10.1016/j.jenvp.2018.11.002.

Batson, C.D., 1991. The Altruism Question: Toward a Social-Psychological Answer. Erlbaum, Hillsdale, NJ.

Batson, C.D. (Ed.), 2011. Altruism in humans. Oxford Univ. Press, Oxford, 329 pp.

Bechtel, M.M., Genovese, F., Scheve, K.F., 2017. Interests, norms and support for the provision of global public goods: the case of climate co-operation. Brit. J. Polit. Sci. 1-23 https://doi.org/10.1017/S0007123417000205.

Bénabou, R., Tirole, J., 2006. Incentives and prosocial behavior. Am. Econ. Rev. 96 (5), 1652-1678. https://doi.org/10.1257/aer.96.5.1652.

Berenguer, J., 2007. The effect of empathy in proenvironmental attitudes and behaviors. Environ. Behav. 39 (2), 269-283. https://doi.org/10.1177/0013916506292937.

Bernauer, T., McGrath, L.F., 2016. Simple reframing unlikely to boost public support for climate policy. Nature Clim Change 6. https://doi.org/10.1038/nclimate2948, 680 E.

Bogaert, S., Boone, C., Declerck, C., 2008. Social value orientation and cooperation in social dilemmas: a review and conceptual model. Br. J. Soc. Psychol. 47 (Pt 3), 453-480. https://doi.org/10.1348/014466607X244970.

Bolderdijk, J.W., Gorsira, M., Keizer, K., Steg, L., 2013a. Values determine the (in) effectiveness of informational interventions in promoting pro-environmental behavior. PLoS One 8 (12), e83911. https://doi.org/10.1371/journal. pone.0083911.

Bolderdijk, J.W., Steg, L., Geller, E.S., Lehman, P.K., Postmes, T., 2013b. Comparing the effectiveness of monetary versus moral motives in environmental campaigning. Nature Clim Change 3 (4), 413-416. https://doi.org/10.1038/nclimate1767.

Bosworth, S.J., Singer, T., Snower, D.J., 2016. Cooperation, motivation and social balance. J. Econ. Behav. Organ. 126, 72-94. https://doi.org/10.1016/j. jebo.2015.12.005.

Bowles, S., 1998. Endogenous preferences: the cultural consequences of markets and other economic institutions. J. Econ. Lit. 36 (1), 75-111.

Bowles, S., 2008. Policies designed for self-interested citizens may undermine "the moral sentiments": evidence from economic experiments. Science (New York, N.Y.) 320 (5883), 1605-1609. https://doi.org/10.1126/science.1152110.

Bratanova, B., Loughnan, S., Gatersleben, B., 2012. The moral circle as a common motivational cause of cross-situational pro-environmentalism. Eur. J. Soc. Psychol. 42 (5), 539-545. https://doi.org/10.1002/ejsp.1871.

Camerer, C., Thaler, R., 1995. Anomalies: ultimatums, dictators and manners. J. Econ. Perspect. 9 (2), 209-219.

Cameron, L.A., 1999. Raising the stakes in the ultimatum game: experimental evidence from Indonesia. Economic inquiry: journal of the Western Economic Association International 37 (1), 47-59.

Cameron, L.D., Brown, P.M., Chapman, J.G., 1998. Social value orientations and decisions to take proenvironmental action1. J Appl Social Pyschol 28 (8), 675-697. https://doi.org/10.1111/j.1559-1816.1998.tb01726.x.

Cheung, W.-Y., Luke, M.A., Maio, G.R., 2014. On attitudes towards humanity and climate change: the effects of humanity esteem and self-transcendence values on environmental concerns. Eur. J. Soc. Psychol. 44 (5), 496-506. https://doi.org/ 10.1002/ejsp.2037.

Chong, D., Druckman, J.N., 2007. Framing theory. Annu. Rev. Polit. Sci. 10 (1), 103-126. https://doi.org/10.1146/annurev.polisci.10.072805.103054.

Cialdini, R.B., Reno, R.R., Kallgren, C.A., 1990. A focus theory of normative conduct: recycling the concept of norms to reduce littering in public places. J. Pers. Soc. Psychol. 58 (6), 1015-1026. https://doi.org/10.1037/0022-3514.58.6.1015.

Cooper, D.J., Kagel, J.H., 2016. Other-regarding preferences: a selective survey of experimental results. In: Kagel, J.H., Roth, A.E. (Eds.), The Handbook of Experimental Economics, Vol. 2. Princeton University Press, Princeton, pp. 217-275.

Crimston, D., Bain, P.G., Hornsey, M.J., Bastian, B., 2016. Moral expansiveness: examining variability in the extension of the moral world. J. Pers. Soc. Psychol. 111 (4), 636-653. https://doi.org/10.1037/pspp0000086.

Czap, N.V., Czap, H.J., Khachaturyan, M., Lynne, G.D., Burbach, M., 2012. Walking in the shoes of others: experimental testing of dual-interest and empathy in environmental choice. J. Socio-Econ. 41 (5), 642-653. https://doi.org/10.1016/j. socec.2012.05.005.

Czap, N.V., Czap, H.J., Lynne, G.D., Burbach, M.E., 2015. Walk in my shoes: nudging for empathy conservation. Ecol. Econ. 118, 147-158. https://doi.org/10.1016/j. ecolecon.2015.07.010.

* Papers used in the literate review are marked with asterisk
Czap, N.V., Czap, H.J., Banerjee, S., Burbach, M.E., 2019. Encouraging farmers' participation in the conservation stewardship program: a field experiment. Ecol. Econ. 161, 130-143. https://doi.org/10.1016/j.ecolecon.2019.03.010.

de Dominicis, S., Schultz, P.W., Bonaiuto, M., 2017. Protecting the environment for selfinterested reasons: altruism is not the only pathway to sustainability. Front. Psychol. 8, 1065. https://doi.org/10.3389/fpsyg.2017.01065.

Dequech, D., 2002. The demarcation between the "old" and the "new" institutional economics: recent complications. Journal of Economic Issues 36 (2), 565-572. https://doi.org/10.1080/00213624.2002.11506501.

Diekmann, A., Preisendörfer, P., 2003. Green and greenback. Ration. Soc. 15 (4), 441-472. https://doi.org/10.1177/1043463103154002.

Dietz, T., Fitzgerald, A., Shwom, R., 2005. Environmental values. Annu. Rev. Environ. Resour. 30 (1), 335-372. https://doi.org/10.1146/annurev. energy.30.050504.144444.

Dietz, T., Duan, R., Nalley, J., van Witsen, A., 2018. Social support for water quality: the influence of values and symbolic racism. Hum. Ecol. Rev. 24 (1).

Dobson, A., Bell, D. (Eds.), 2006. Environmental Citizenship. MIT Press, Cambridge, Mass, 296 pp.

Dogan, E., Bolderdijk, J.W., Steg, L., 2014. Making small numbers count: environmental and financial feedback in promoting eco-driving behaviours. J. Consum. Policy 37 (3), 413-422. https://doi.org/10.1007/s10603-014-9259-z.

Drews, S., van den Bergh, J.C.J.M., 2016. What explains public support for climate policies? A review of empirical and experimental studies. Clim. Pol. 16 (7), 855-876. https://doi.org/10.1080/14693062.2015.1058240.

Evans, L., Maio, G.R., Corner, A., Hodgetts, C.J., Ahmed, S., Hahn, U., 2013. Self-interest and pro-environmental behaviour. Nature Clim Change 3 (2), 122-125. https://doi. org/10.1038/NCLIMATE1662.

Falk, A., Kosfeld, M., 2006. The hidden costs of control. Am. Econ. Rev. 96 (5), 1611-1630. https://doi.org/10.1257/aer.96.5.1611.

Farrow, K., Grolleau, G., Ibanez, L., 2017. Social norms and pro-environmental behavior: a review of the evidence. Ecol. Econ. 140, 1-13. https://doi.org/10.1016/j. ecolecon.2017.04.017.

Fehr, E., Gächter, S., 2002. Altruistic punishment in humans. Nature 415, 137-140.

Fehr, E., Schmidt, K.M., 2006. Chapter 8 The economics of fairness, reciprocity and altruism - Experimental evidence and new theories. In: Mercier Ythier, J., Kolm, S. C. (Eds.), Handbook of the Economics of Giving, Altruism and Reciprocity, 1st ed, vol. 1. Elsevier, Amsterdam, New York, pp. 615-691.

Fehr, E., Tougareva, E., Fischbacher, U., 2014. Do high stakes and competition undermine fair behaviour? Evidence from Russia. J. Econ. Behav. Organ. 108, 354-363. https://doi.org/10.1016/j.jebo.2013.09.005.

Ferraro, P.J., Price, M.K., 2013. Using nonpecuniary strategies to influence behavior: evidence from a large-scale field experiment. Rev. Econ. Stat. 95 (1), 64-73. https:// doi.org/10.1162/REST_a_00344.

Ferraro, P.J., Miranda, J.J., Price, M.K., 2011. The persistence of treatment effects with norm-based policy instruments: evidence from a randomized environmental policy experiment. Am. Econ. Rev. 101 (3), 318-322. https://doi.org/10.1257/ aer.101.3.318.

Fischbacher, U., Gächter, S., Fehr, E., 2001. Are people conditionally cooperative? Evidence from a public goods experiment. Econ. Lett. 71 (3), 397-404. https://doi. org/10.1016/S0165-1765(01)00394-9.

Franco, A., Malhotra, N., Simonovits, G., 2014. Social science. Publication bias in the social sciences: unlocking the file drawer. Science (New York, N.Y.) 345 (6203), 1502-1505. https://doi.org/10.1126/science.1255484.

Frey, B.S., Jegen, R., 2001. Motivation crowding theory. J Economic Surveys 15 (5), 589-611. https://doi.org/10.1111/1467-6419.00150.

Frey, U.J., Pirscher, F., 2018. Willingness to pay and moral stance: the case of farm animal welfare in Germany. PLoS One 13 (8), e0202193. https://doi.org/10.1371/ journal.pone.0202193.

Frey, B.S., Stutzer, A., 2006. Environmental morale and motivation. SSRN Journal. https://doi.org/10.2139/ssrn.900370.

Gneezy, U., Rustichini, A., 2000. A fine is a price. J. Leg. Stud. 29 (1), 1-17. https://doi, org/10.1086/468061.

Gosnell, G.K., 2018. Communicating resourcefully: a natural field experiment on environmental framing and cognitive dissonance in going paperless. Ecol. Econ. 154, 128-144. https://doi.org/10.1016/j.ecolecon.2018.07.020.

Grolleau, G., Midler, E., Mzoughi, N., 2017. Behavioral insights for the analysis of green tips. Ecol. Econ. 134, 258-262. https://doi.org/10.1016/j.ecolecon.2016.12.010.

Hafner, R., Elmes, D., Read, D., 2017. Exploring the role of messenger effects and feedback frames in promoting uptake of energy-efficient technologies. Curr. Psychol. 25 (1), 273. https://doi.org/10.1007/s12144-017-9717-2.

Hafner, B.R., Elmes, D., Read, D., White, M.P., 2019. Exploring the role of normative, financial and environmental information in promoting uptake of energy efficient technologies. J. Environ. Psychol. 63, 26-35. https://doi.org/10.1016/j. jenvp.2019.03.004.

Hardin, G., 1968. The tragedy of the commons. Science (New York, N.Y.) 162 (3859), 1243-1248. https://doi.org/10.1126/science.162.3859.1243.

Harring, N., Jagers, S., Matti, S., 2017. Public support for pro-environmental policy measures: examining the impact of personal values and ideology. Sustainability 9 (5), 679. https://doi.org/10.3390/su9050679.

Henrich, J., Boyd, R., Bowles, S., Camerer, C., Fehr, E., Gintis, H., McElreath, R., 2001. In search of homo economicus: behavioral experiments in 15 small-scale societies. Am. Econ. Rev. 91 (2), 73-84.

Hodgson, G.M., 2000. What is the essence of institutional economics? Journal of Economic Issues 34 (2), 317-329. https://doi.org/10.1080/ 00213624.2000 .11506269$. 
Kahneman, D., Knetsch, J.L., Thaler, R.H., 1986. Fairness and the assumptions of economics. J. Bus. 59 (S4), S285. https://doi.org/10.1086/296367.

Karapetyan, D., d'Adda, G., 2014. Determinants of conservation among the rural poor: a charitable contribution experiment. Ecol. Econ. 99, 74-87. https://doi.org/10.1016/ j.ecolecon.2014.01.009.

Klimecki, O.M., Leiberg, S., Lamm, C., Singer, T., 2013. Functional neural plasticity and associated changes in positive affect after compassion training. Cerebral cortex (New York, N.Y: 1991) 23 (7), 1552-1561. https://doi.org/10.1093/cercor/bhs142.

Lepenies, R., Malecka, M., 2019. The ethics of behavioural public policy. In: Strassheim, H., Beck, S. (Eds.), Handbook of Behavioural Change and Public Policy. Edward Elgar Publishing, Cheltenham, U.K., pp. 513-525

Lepper, M.R., Greene, D., Nisbett, R.E., 1973. Undermining children's intrinsic interest with extrinsic reward: a test of the "overjustification" hypothesis. J. Pers. Soc. Psychol. 28 (1), 129-137. https://doi.org/10.1037/h0035519.

Liberman, V., Samuels, S.M., Ross, L., 2004. The name of the game: predictive power of reputations versus situational labels in determining prisoner's dilemma game moves. Personal. Soc. Psychol. Bull. 30 (9), 1175-1185. https://doi.org/10.1177/ 0146167204264004.

Lindenberg, S., Steg, L., 2007. Normative, gain and hedonic goal frames guiding environmental behavior. J Social Issues 63 (1), 117-137. https://doi.org/10.1111/ j.1540-4560.2007.00499.x.

Loureiro, A., Lima, M.L., 2019. Energy-saving behavior: the different roles of altruism and of environmentalism. Univ Psychol 18 (1), 1-12. https://doi.org/10.11144/ Javeriana.upsy18-1.esbd.

Lynne, G.D., Czap, N.V., Czap, H.J., Burbach, M.E., 2016. A theoretical foundation for empathy conservation: toward avoiding the tragedy of the commons. RBE 3 (3-4), 243-279. https://doi.org/10.1561/105.00000052.

Nolan, J.M., Schultz, P.W., 2015. Prosocial behavior and environmental action. In: Schroeder, D.A., Graziano, W.G. (Eds.), The Oxford Handbook of Prosocial Behavior. Oxford University Press, Oxford, New York, pp. 626-652.

Nyborg, K., 2018. Social norms and the environment. Annu. Rev. Resour. Econ. 10 (1), 405-423. https://doi.org/10.1146/annurev-resource-100517-023232.

Olson, M., 1965. The Logic of Collective Action: Public Goods and the Theory of Groups. Harvard Univ. Press, Cambridge, London.

O'Neill, S., Williams, H.T.P., Kurz, T., Wiersma, B., Boykoff, M., 2015. Dominant frames in legacy and social media coverage of the IPCC fifth assessment report. Nature Clim Change 5 (4), 380-385. https://doi.org/10.1038/NCLIMATE2535.

Ortiz-Riomalo, J.F., Koessler, A.-K., Engel, S., 2021. Inducing perspective-taking for prosocial behaviour in natural resource management, EconStor Preprints 228966. ZBW - Leibniz Centre for Economics.

Ostrom, E., 1990. Governing the Commons: The Evolution of Institutions for Collective Action. Cambridge University Press, New York, NY.

Ovchinnikova, N.V., Czap, H.J., Lynne, G.D., Larimer, C.W., 2009. "I don't want to be selling my soul": two experiments in environmental economics. J. Socio-Econ. 38 (2), 221-229. https://doi.org/10.1016/j.socec.2008.10.010.

Pahl, S., Bauer, J., 2013. Overcoming the distance. Environ. Behav. 45 (2), 155-169. https://doi.org/10.1177/0013916511417618.

Pascual, U., Balvanera, P., Díaz, S., Pataki, G., Roth, E., Stenseke, M., Watson, R.T., Başak Dessane, E., Islar, M., Kelemen, E., Maris, V., Quaas, M., Subramanian, S.M., Wittmer, H., Adlan, A., Ahn, S., Al-Hafedh, Y.S., Amankwah, E., Asah, S.T., Berry, P., Bilgin, A., Breslow, S.J., Bullock, C., Cáceres, D., Daly-Hassen, H., Figueroa, E., Golden, C.D., Gómez-Baggethun, E., González-Jiménez, D., Houdet, J., Keune, H., Kumar, R., Ma, K., May, P.H., Mead, A., O'Farrell, P., Pandit, R., Pengue, W., PichisMadruga, R., Popa, F., Preston, S., Pacheco-Balanza, D., Saarikoski, H., Strassburg, B. B., van den Belt, M., Verma, M., Wickson, F., Yagi, N., 2017. Valuing nature's contributions to people: the IPBES approach. Curr. Opin. Environ. Sustain. 26-27, 7-16. https://doi.org/10.1016/j.cosust.2016.12.006.

Pfattheicher, S., Sassenrath, C., Schindler, S., 2016. Feelings for the Suffering of Others and the Environment: Compassion Fosters Proenvironmental Tendencies 48 (7), 929-945.

Rode, J., Gómez-Baggethun, E., Krause, T., 2015. Motivation crowding by economic incentives in conservation policy: a review of the empirical evidence. Ecol. Econ. 117, 270-282. https://doi.org/10.1016/j.ecolecon.2014.11.019.

Rogall, H., 2002. Neue Umweltökonomie-Ökologische Ökonomie. VS Verlag für Sozialwissenschaften.
Sagoff, M., 1988. The Economy of the Earth: Philosophy, Law, and the Environment, 2nd ed. Cambridge University Press, Cambridge, New York.

Schmidt, K., Fehr, E., 2001. Theories of Fairness and Reciprocity - Evidence and Economic Applications. University of Zurich. https://doi.org/10.5167/UZH-51976.

Schultz, P.W., 2001. The structure of environmental concern: concern for self, other people, and the biosphere. J. Environ. Psychol. 21 (4), 327-339. https://doi.org/ 10.1006/jevp.2001.0227.

Schultz, P.W., Zelezny, L.C., 1998. Values and proenvironmental behavior. J. Cross-Cult. Psychol. 29 (4), 540-558. https://doi.org/10.1177/0022022198294003.

Schultz, W., Zelezny, L., 1999. Values as predictors of environmental attitudes: evidence for consistendy across 14 countries. J. Environ. Psychol. 19 (3), 255-265. https:// doi.org/10.1006/jevp.1999.0129.

Schwartz, S.H., 1977. Normative influence on altruism. In: Berkowitz, L. (Ed.), Advances in Experimental Social Psychology. Academic Press, New York, NY, pp. 221-279.

Schwartz, S.H., 1996. Value priorities and behavior: applying a theory of integrated value systems. In: Seligman, C., Olson, J.M., Zanna, M.P. (Eds.), The Psychology of Values. Erlbaum, Mahwah, NJ, pp. 1-25.

Severson, A.W., Coleman, E.A., 2015. Moral frames and climate change policy attitudes*. Social Science Q 96 (5), 1277-1290. https://doi.org/10.1111/ssqu.12159.

Sevillano, V., Aragonés, J.I., Schultz, P.W., 2013. Altruism and beyond: the motivational based of pro-environmental behavior. In: Corral-verdugo, V. (Ed.), Psychological Approaches to Sustainability - Current Trends in Theory. rese. Nova Science Publishers Inc, pp. 161-184.

Sheldon, K.M., Nichols, C.P., 2009. Comparing democrats and republicans on intrinsic and extrinsic values. J Appl Social Pyschol 39 (3), 589-623. https://doi.org/ 10.1111/j.1559-1816.2009.00452.x.

Shelton, M.L., Rogers, R.W., 1981. Fear-arousing and empathy-arousing appeals to help: the pathos of persuasion. J Appl Social Pyschol 11 (4), 366-378. https://doi.org/ 10.1111/j.1559-1816.1981.tb00829.x.

Siebenhüner, B., 2001. Homo sustinens: Auf dem Weg zu einem Menschenbild der Nachhaltigkeit.

Simon, H.A., 1972. Theories of bounded rationality. In: McGuire, C.B., Radner, R. (Eds.), Decision and Organization. North-Holland Publishing Company, pp. 161-176.

Singer, P., 1981. The Expanding Circle: Ethics and Sociobiology. Clarendon, Oxford.

Singer, T., Kok, B.E., Bornemann, B., Zurborg, S., Bolz, M., Bochow, C., 2016. The ReSource Project: Background, Design, Samples, and Measurements, Second edition. Leipzig.

Singh, S.P., Swanson, M., 2017. How issue frames shape beliefs about the importance of climate change policy across ideological and partisan groups. PLoS One 12 (7), e0181401. https://doi.org/10.1371/journal.pone.0181401.

Spence, A., Poortinga, W., Pidgeon, N., 2012. The psychological distance of climate change. Risk Analysis : An Official Publication of the Society for Risk Analysis 32 (6), 957-972. https://doi.org/10.1111/j.1539-6924.2011.01695.x.

Stern, P.C., 2000. Toward a coherent theory of environmentally significant behavior. J. Soc. Issues 56 (3), 407-424. https://doi.org/10.1111/0022-4537.00175.

Stern, P.C., Dietz, T., Abel, T., Guagnano, G., Kalof, L., 1999. A value-belief-norm theory of support for social movements: the case of environmentalism. Hum. Ecol. Rev. 6 (2), 81-97.

Straßheim, H., Beck, S., 2019. Handbook of Behavioural Change and Public Policy. Edward Elgar, Cheltenham.

Thøgersen, J., Crompton, T., 2009. Simple and painless? The limitations of spillover in environmental campaigning. J. Consum. Policy 32 (2), 141-163. https://doi.org/ 10.1007/s10603-009-9101-1.

Truelove, H.B., Carrico, A.R., Weber, E.U., Raimi, K.T., Vandenbergh, M.P., 2014. Positive and negative spillover of pro-environmental behavior: an integrative review and theoretical framework. Glob. Environ. Chang. 29, 127-138. https://doi.org/ 10.1016/j.gloenvcha.2014.09.004.

van Lange, P.A.M., Bekkers, R., Chirumbolo, A., Leone, L., 2012. Are conservatives less likely to be prosocial than liberals? From games to ideology, political preferences and voting. Eur. J. Personal. 26 (5), 461-473. https://doi.org/10.1002/per.845.

Verplanken, B., Holland, R.W., 2002. Motivated decision making: effects of activation and self-centrality of values on choices and behavior. J. Pers. Soc. Psychol. 82 (3), 434-447. https://doi.org/10.1037//0022-3514.82.3.434.

Zettler, I., Hilbig, B.E., Haubrich, J., 2011. Altruism at the ballots: predicting political attitudes and behavior. J. Res. Pers. 45 (1), 130-133. https://doi.org/10.1016/j. jrp.2010.11.010. 